\title{
MORPHOLOGY AND STRATAL GEOMETRY OFTHE ANTARCTIC CONTINENTAL SHELF: INSIGHTS FROM MODELS
}

\author{
Uri S. ten Brink, Christopher Schneider, and Aaron H. Johnson \\ U.S.Geological Survey, Woods Hole, Massachusetts
}

\begin{abstract}
Reconstruction of past ice-sheet fluctuations from the stratigraphy of glaciated continental shelves requires understanding of the relationships among the stratal geometry, glacial and marine sedimentary processes, and ice dynamics. We investigate the formation of the morphology and the broad stratal geometry of topsets on the Antarctic continental shelf with numerical models. Our models assume that the stratal geometry and morphology are principally the results of time-integrated effects of glacial erosion and sedimentation related to the location of the seaward edge of the grounded ice. The location of the grounding line varies with time almost randomly across the shelf. With these simple assumptions, the models can successfully mimic salient features of the morphology and the stratal geometry. The models suggest that the current shelf has gradually evolved to its present geometry by many glacial advances and retreats of the grounding line to different locations across the shelf. The locations of the grounding line do not appear to be linearly correlated with either fluctuations in the $\delta^{18} \mathrm{O}$ record (which presumably represents changes in the global ice volume) or with the global sea-level curve, suggesting that either a more complex relationship exists or local effects dominate. The models suggest that erosion of preglacial sediments is confined to the inner shelf, and erosion decreases and deposition increases toward the shelf edge. Some of the deposited glacial sediments must be derived from continental erosion. The sediments probably undergo extensive transport and reworking obliterating much of the evidence for their original depositional environment. The flexural rigidity and the tectonic subsidence of the underlying lithosphere modify the bathyrnetry of the shelf, but probably have little effect on the stratal geometry. Our models provide several guidelines for the interpretation of unconformities, the nature of preserved topset deposits, and the significance of progradation versus aggradation of shelf sediments.
\end{abstract}

\section{INTRODUCTION}

Sediment erosion, transport, and deposition across continental shelves are, in general, aqueous processes, but during Cenozoic times, the Antarctic shelf has also been partly affected by the presence of grounded ice. A variety of glacial and glaciomarineerosional, transport, and depositional processes may have acted on the shelf, some of which were related to climate (temperate vs. polar ice sheet) and to location (mountain glacier, ice shelf, ice streams, etc.) [e.g., Drewry, 1986; Blankenship et al., 1986; Syvitski, 1989; Boulton, 1990; Powell, 1990; Anderson and Ashley, 1991]. The processes include erosion of dry rock by abrasion, subglacial sediment erosion and transport by a water-saturated deformable till layer, \&position of englacial debris, plume discharge in front of the grounding line, ice raft- ing, and more. In addition, many aqueous processes take place ahead of the grounding line, such as turbidity and contour currents, debris flow, wave-base erosion, and open marine biogenic sedimentation [Domack et al., 1991]. In modeling the stratigraphy of glaciated shelves, one should bear in mind that two significant differences exist between glacial and aqueous processes. (1) Aqueous processes almost always transport material downslope, whereas glacial processes can transport material up gentle slopes [e.g., Drewry, 19861; (2) Waterborne sediments generally fill the accommodation space on the shelf first, but because grounded ice fills the shelfs accommodation space, glaciomarine sediments are preferentially transported to the continental slope.

Despite the many different glacial and glaciomarine processes that have probably operated at different times, locations, and scales [Anderson and Ashley, 1991], the 


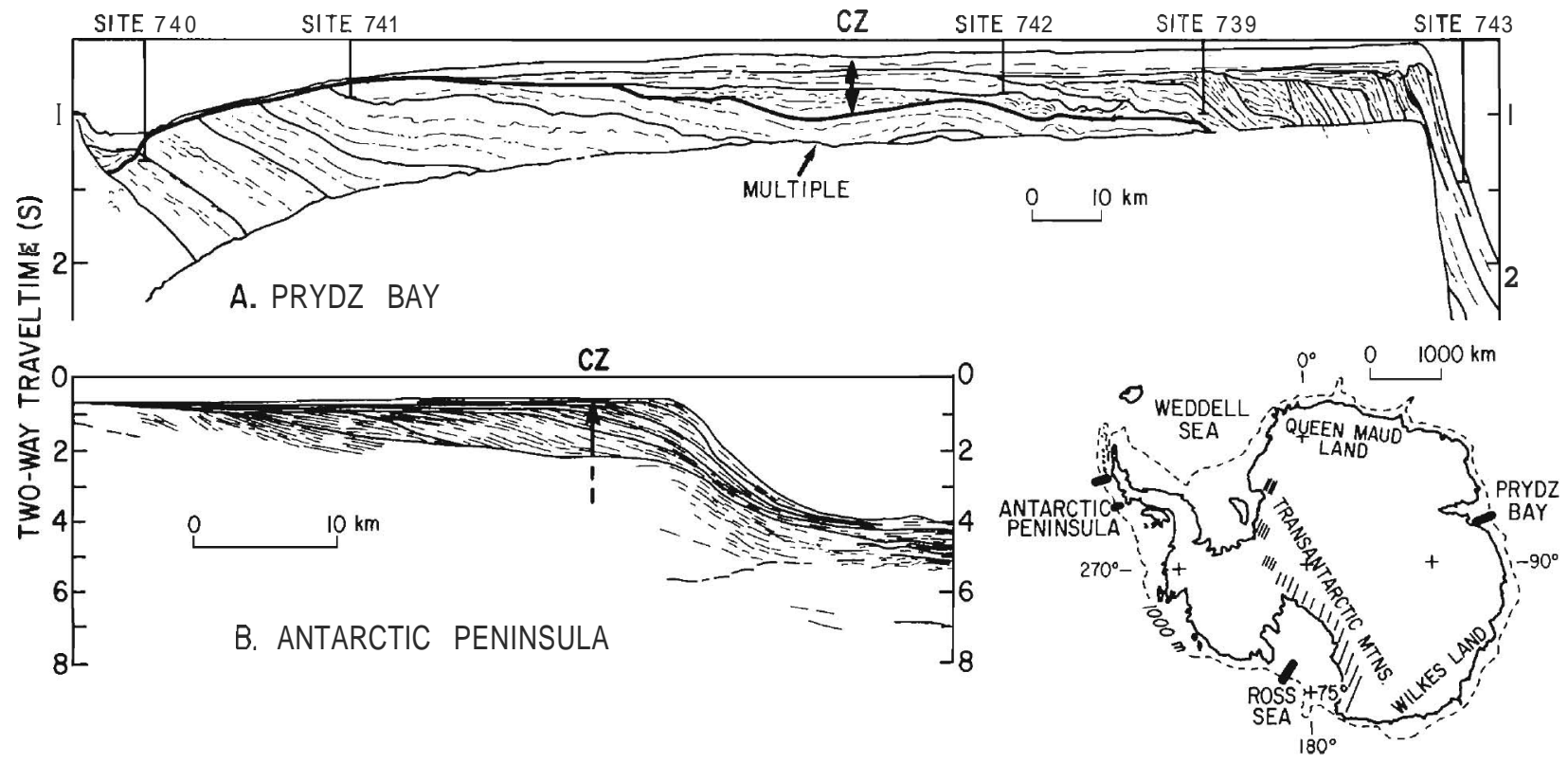

Fig. 1. Line drawings of seismic lines across the Antarctic continental shelf at (A) Prydz Bay [Cooper et al., 1991a], and (B) the central Antarctic Peninsula (Larter and Barker, 1991). CZ Cenozoic glacial sedimentary section. Sites 739-743 - Ocean Drilling Program drill sites during Leg 119.

stratal geometry of the shelf generally has the same characteristicsat different locations around the Antarctic margin. The stratal geometry of the Cenozoic Antarctic shelf resembles the geometry of high-stand and shelfmargin-wedge systems tracts in low-latitude shelves (Figure 1b; Bartek et al. [1991]). The equivalent stratal geometries to low-stand and transgressive systems tracts (in low latitude) have not been identified [Cooperet ul., 1991b]. Aggradation of thin, continuous layers and extensive seaward progradation of proglacial glaciomarine sediments characterize the depositional sequences of the Antarctic shelf (Figure 2a and the upper section of Figure 2b; Anderson [1991]; Alonso et al. [1992]). Toplap and offlap relations are observed on the outer shelf (Figure lb), where only a few unconformities truncate steeply dipping prograded sequences (Figure la). However, intermediate-resolution seismic-reflection data show that some unconformities are an amalgamation of several erosional surfaces that converge updip and along strike [Anderson and Bartek, 1992]. In dip section, the reflectors are planar to subhorizontal, and in strike section they are broad (tens of $\mathrm{km}$ wide) and tens of meters deep depressions that are interpreted as glacial troughs [Anderson and Bartek, 19921. Some acoustically massive sedimentary bodies, tens of meters thick and kilometers to tens of $\mathrm{km}$ long, occur in the pre-
Pliocene sequences of the Ross Sea and are interpreted as till tongues [Andersonand Bartek, 19921.

The morphology of the Antarctic shelf is unusual but generally similar around the continent [Johnsonet al., 1982; ten Brink and Cooper, 19921. Unlike the depth of low-latitudeshelves, which generally increases gradually from the coast to shelf edge depths of 100-200 m, the Antarctic shelf (Figure 1) is commonly deeper at the inner shelf than at the shelf edge (henceforth, "reverse" morphology). A trough up to $1500 \mathrm{~m}$ deep often occupies the inner shelf, and the outer shelf may be 200-400 $\mathrm{m}$ deep. This similar shelf morphology around the continent is particularly striking, because the thermal and tectonic histories of different Antarctic margins are so different. For example, the break-up of East Antarctica from India in Prydz Bay (Figure la) occurred $128 \mathrm{Ma}$ [Lawveret al., 1991]; therefore, residual thermal subsidence from rifting since the start of glaciation $-40 \mathrm{Ma}$, has been small. The Pacific margin of the Antarctic Peninsula (Figure lb) was, on the other hand, subject to collision and subduction until 3-4 Ma [Larter and Barker, 1991], implying vertical tectonic movements throughout Cenozoic glaciation.

Whether the similarities in the characteristic morphology and stratal geometry are due to one or few dominant processes, or whether the combination of all 




Fig. 2. (A) Seismic profile and interpreted line drawing across the Ross Sea shelf [Alonso et al., 1991]. 271, 272 - Deep Sea Drilling Project Leg 28 drill sites. (B) Line drawing of seismic profile across the southern Antarctic Peninsula shelf [Bart and Anderson, 1994]. See Figure 1 for locations.

glacial and glaciomarine erosion, transport, and deposition processes should always form the same morphology and stratal geometry is unknown. Because we cannot presently separate the relative contributions of different physical processes with time, location, and scale, we cannot construct a process-basedmodel. We instead, propose a model in which the morphology and the regional stratal geometry of glaciated shelves are principally the results of time-integrated effects of glacial erosion and sedimentation and the location of the ice grounding line [ten Brink and Schneider, in press]. The model presented in this paper is two dimensional to simplify the calculations and the interpretation of the modeling results, although glacial movements also take place along the shelf (a three-dimensional process) [e.g., Eittreim et al., 1995].

The purpose of the work is to suggest a conceptual framework for the interpretation of the Antarctic shelf stratigraphy, in particular, to investigate whether detailed stratigraphic analysis of the shelf deposits can yield a detailed record of the extent of Antarctic ice sheets through time, and to put some broad constraints on the integrated patterns of glacial sedimentation and erosion. We start the paper by describing the model and 
the results of a reference model. We then introduce perturbations to the model parameters in order to better understand their influence on the stratal geometry and the sea-floor morphology. We investigate whether the locations of the glacial grounding line through time are related to the global sea-level curve or to fluctuations of the global ice volume via the oxygen isotope record. Finally, we discuss observations and inferencesfrom polar shelves, which are in agreement with the model assumptions and conclusions.

\section{MODELS}

In this section, we describe the parameters of the reference model, give their numerical values, and discuss the rationale for their choice. In later sections, we vary those values to investigate their contributions to the stratal geometry and shelf morphology (Table 1 ).

We divided the margin into $\mathrm{N}$ discrete positions ( $N=35$ in most models), and assumed that the glacial grounding line was reaching one of these positions during a particular ice advance or retreat (Figure 3). Because the positions of the grounding line through time are unknown, we ran several sets of models with positions determined by (a) computer-generateduniform random number series, and (b) by linear correlation with the global sea-level curve and with the global $\delta^{18} \mathrm{O}$ record, which presumably represents the global ice-volume changes with time [e.g., Imbrie et al., 19841. The shelf in our model was initially only 20 positions wide, and widened during the model run by sediment progradation to $-25-30$ positions. Therefore, if the position of the grounding line at any particular advance or retreat fell seaward of the shelf edge, the grounding line remained at the shelf edge. The reason behind this model design is that the distance to which the grounding line can reach depends on the driving pressure of the glacier, and not on the location of the shelf edge. The flowing ice does not "know" how far ahead the shelf edge is located, until it reaches there.

The models included 111 steps. We did not distinguish between processes occurring during glacial advance and those occurring during glacial retreat (because deposition and erosion during advance and retreat are presently poorly quantified), but assumed that during each model step, erosion occurs under the grounded glacier and deposition occurs ahead of the grounding line (Figure 3). The number of steps, 111, is small enough to allow graphical representation of the results on paper, yet is large enough to satisfy the statistical requirement that in a random-number-based model, the grounding line should occupy at least once, every one of the N positions. The statistical requirement is for $\mathrm{N}$ In $\mathrm{N}$ steps; [Feller, 1968]. In the random model, a new number between 1 and 35 was picked randomly before each step was calculated. In the oxygen-isotope-based and sea level-based models, the minimum $\delta^{18} \mathrm{O}$ value in the record (which is close to today's value) or the maximum sea level was equated with a grounding-lineposition at the coast $(\mathrm{N}=1)$; the maximum $\delta^{18} \mathrm{O}$ value (or the minimum sea level) was equated with the most seaward position $(\mathrm{N}=35)$; and the remaining values were linearly interpolated.

During each model step, erosion occurred under the grounded glacier and deposition ahead of the grounding line (Figure 3), according to the following pattern: Erosion linearly increased from no erosion at the grounding line to 2 (non-dimensional) units 22 positions behind the grounding line. Deposition linearly decreased from 3.5 units at the grounding line to 0.5 unit 22 positions ahead of the grounding line. The distributions of erosion and deposition in the models were made to fit commonly observed stratigraphic sections (such as in Figures 1 and 2), were functions only of the distance from the grounding line, and were independent of the particular position of the grounding line on the shelf.

The transport capacity (erosion and deposition) of a glacier is probably constant for certain locations and climatic conditions, but the duration of the glacial step may vary. For the sake of generality and simplicity, and because the duration of glacial advance and retreats are presently poorly constrained, time (via rates of processes) was not explicitly included in the model, and the total volume of deposits was kept constant in each step (except in the sea-level model).

All sediments that fell in positions beyond the shelf edge filled the first slope position. When this position was filled to the level of the shelf edge at this step (after isostatic adjustment), it became part of the shelf, and the next position began to fill (Figure 3). The volume of erosion in each step was smaller than the volume of deposition and depended on the location of the grounding line at that step (e.g., no erosion when the grounding line was at the coast). Because the volume of deposition was larger than the volume of erosion, the model implies that part of the glacial sediments must be supplied from erosion onshore.

The model was iteratively adjusted after each step for isostasy (Airy) due to eroded and deposited material. At the beginning of the model run, we added (1) the preglacial bathymeuy (0 to $150 \mathrm{~m}$ ), which increase lin- 
TABLE 1. Summary of model parameters and interpretations

\begin{tabular}{|c|c|c|c|c|}
\hline Model & Variable & Plate & Model effects & Interpretation \\
\hline $\begin{array}{l}\text { Reference (advance } \\
\text { and retreat) }\end{array}$ & $\begin{array}{l}\text { Random fluctuations (slight } \\
\text { bias to shelf edge), tapered } \\
\text { deposition and erosion, } \\
\text { constant sediment volume, } \\
\text { Airy isostasy, moderate } \\
\text { subsidence }\end{array}$ & $1 a, b$ & $\begin{array}{l}\text { Reverse bathymetry, } \\
\text { inner shelf erosion, total } \\
\text { erosion < deposition, thin } \\
\text { continuous layers, pinch } \\
\text { out, progradation change } \\
\text { upward to aggradation }\end{array}$ & $\begin{array}{l}\text { Random approach fits ob- } \\
\text { servations and can serve as } \\
\text { an initial conceptual model }\end{array}$ \\
\hline $\begin{array}{l}\text { Retreat from shelf } \\
\text { edge }\end{array}$ & $\begin{array}{l}\text { Even step - grounding line } \\
\text { at shelf edge, Odd step - at } \\
\text { random location }\end{array}$ & $1 \mathrm{c}, \mathrm{d}$ & $\begin{array}{l}\text { More progradation and } \\
\text { inner shelf erosion, less } \\
\text { aggradation }\end{array}$ & Same as above \\
\hline $\begin{array}{l}\text { Perturbations to ref- } \\
\text { erence model }\end{array}$ & $\begin{array}{l}\text { Fix } 20 \text { steps at shelf edge, } \\
10 \text { steps at coast }\end{array}$ & $2 a, b$ & $\begin{array}{l}\text { Unconformity; } \\
\text { thick mid-shelf sediments }\end{array}$ & $\begin{array}{l}\text { Unconformity due to ice at } \\
\text { shelf edge, shelf sediments } \\
\text { only partially preserved }\end{array}$ \\
\hline $\begin{array}{l}\text { Grounding line ei- } \\
\text { ther at coast or at } \\
\text { shelf edge }\end{array}$ & $\begin{array}{l}\text { a) Tapered deposition } \\
\text { b) Constant-thickness } \\
\text { deposition }\end{array}$ & $\begin{array}{l}\text { a) } 3 a \\
\text { b) } 3 b\end{array}$ & $\begin{array}{l}\text { Morphology deepens sea- } \\
\text { ward, no unconformity, } \\
\text { no inner shelf erosion }\end{array}$ & $\begin{array}{l}\text { Grounding line must lie at } \\
\text { intermediate points }\end{array}$ \\
\hline Randomness & $\begin{array}{l}\text { a) Heavily skewed } \\
\text { b) Slightly = reference } \\
\text { c) Purely random }\end{array}$ & $\begin{array}{l}\text { a) } 4 a \\
\text { b) } 4 b \\
\text { c) } 4 c\end{array}$ & $\begin{array}{l}\text { Skewness increases } \\
\text { erosion, progradation } \\
\text { and unconformities }\end{array}$ & $\begin{array}{l}\text { Skewness may depend on } \\
\text { shelf width, ice driving } \\
\text { pressure }\end{array}$ \\
\hline Erosion pattern & No erosion & $5 \mathrm{a}$ & No inner shelf erosion & Subglacial erosion needed \\
\hline Deposition pattern & $\begin{array}{l}\text { a) Logarithmic } \\
\text { b) Constant } \\
\text { c) Tapered = reference }\end{array}$ & $\begin{array}{l}\text { a) } 5 \mathrm{~b} \\
\text { b) } 5 \mathrm{c} \\
\text { c) } 5 \mathrm{~d}\end{array}$ & $\begin{array}{l}\text { a) Irregular pods } \\
\text { b) Offlap in midshelf } \\
\text { c) Thin layers, pinchout }\end{array}$ & $\begin{array}{l}\text { a) Repeated advances rework } \\
\text { and create uniform layers } \\
\text { b,c) Tapered preferred }\end{array}$ \\
\hline $\begin{array}{l}\text { Abrupt change at step } \\
56 \text { in volume of } \\
\text { deposition and } \\
\text { erosion (tapered } \\
\text { deposition pattern } \\
\text { during all steps) }\end{array}$ & $\begin{array}{l}\text { a) Reference model changes } \\
\text { to } 2 \mathrm{x} \text { deposition and } 112 \mathrm{x} \\
\text { erosion of reference model } \\
\text { b) } 2 \mathrm{x} \text { deposition and } 1 / 2 \mathrm{x} \\
\text { erosion change to reference } \\
\text { model }\end{array}$ & $\begin{array}{l}\text { a) } 6 a \\
\text { b) } 6 b\end{array}$ & $\begin{array}{l}\text { a) Minor changes } \\
\text { b) Minor changes }\end{array}$ & $\begin{array}{l}\text { Change in sediment volume } \\
\text { does not affect internal } \\
\text { stratal geometry, only } \\
\text { change from aggradation to } \\
\text { progaradation and vice } \\
\text { versa }\end{array}$ \\
\hline $\begin{array}{l}\text { Abrupt change in } \\
\text { volume as above, } \\
\text { also change in } \\
\text { deposition pattern }\end{array}$ & $\begin{array}{l}\text { When deposition is } \\
\text { doubled, it's pattern is } \\
\text { constant with distance } \\
\text { a) As a) above } \\
\text { b) As b) above }\end{array}$ & $\begin{array}{l}\text { a) } 6 c \\
\text { b) } 6 \mathrm{~d}\end{array}$ & $\begin{array}{l}\text { a) Steps 56-111 lap on } \\
\text { steps 1-55 } \\
\text { b) Steps 56-111 lap off } \\
\text { steps 1-55; Unconformity } \\
\text { between two parts }\end{array}$ & $\begin{array}{l}\text { Changes in distirbution } \\
\text { pattern affect stratal } \\
\text { geometry }\end{array}$ \\
\hline $\begin{array}{l}\text { Isostasy and thermal } \\
\text { subsidence }\end{array}$ & $\begin{array}{l}\text { a) Airy = reference } \\
\text { b) Flexure } \\
\text { c) Double subsidence rate } \\
\text { d) Evolution of bathymetry } \\
\text { for double subsidence rate }\end{array}$ & $\begin{array}{l}\text { a) } 7 a \\
\text { b) } 7 b \\
\text { c) } 7 c \\
\text { d) } 7 d\end{array}$ & $\begin{array}{l}\text { b) Bathymetry bows down } \\
\text { at shelf edge, sediments } \\
\text { extend farther ashore } \\
\text { c) Flat bathymetry, } \\
\text { greater depth; b,c) Stratal } \\
\text { geometry not changed }\end{array}$ & $\begin{array}{l}\text { Isostasy and tectonic } \\
\text { subsidence modify } \\
\text { bathymetric profile, but } \\
\text { have little effect on stratal } \\
\text { geometry }\end{array}$ \\
\hline $\begin{array}{l}\text { Sea-level curve for } \\
\text { last } 30 \mathrm{MA}\end{array}$ & $\begin{array}{l}\text { Maxima and minima of } \\
\text { global sea level, constant } \\
\text { transport rate }\end{array}$ & $8 a, b$ & $\begin{array}{l}\text { a) Offlap } \\
\text { b) Large variability in } \\
\text { layer thickness, some } \\
\text { layer thickening to shore }\end{array}$ & $\begin{array}{l}\text { No simple relation with } \\
\text { grounding line position, } \\
\text { but coarse curve makes } \\
\text { interpretation doubtful }\end{array}$ \\
\hline$\delta^{18} \mathrm{O}$ for last $0.8 \mathrm{Ma}$ & $\begin{array}{l}\text { Sampling every } 7.1 \mathrm{ky} \\
\text { leads to gradual advance and } \\
\text { retreat over several cycles }\end{array}$ & $8 \mathrm{c}, \mathrm{d}$ & $\begin{array}{l}\text { Periodic unconformities, } \\
\text { sediments preserved for } \\
\text { every ice volume decrease }\end{array}$ & $\begin{array}{l}\text { Sedimentation during } \\
\text { gradual ice movements fits } \\
\text { some observations }\end{array}$ \\
\hline$\delta^{18} \mathrm{O}$ for last $2.5 \mathrm{Ma}$ & $\begin{array}{l}\text { a) Sampling every } 16.6 \mathrm{ky} \\
\text { leads to rapid fluctuations } \\
\text { b) Trend removed }\end{array}$ & $\begin{array}{l}\text { a) } 9 a, b \\
\text { b) } 9 c, d\end{array}$ & $\begin{array}{l}\text { a) Offlap } \\
\text { b) Sea floor concave down }\end{array}$ & $\begin{array}{l}\text { No simple relation between } \\
\delta^{18} \mathrm{O} \text { and glacial } \\
\text { fluctuations }\end{array}$ \\
\hline
\end{tabular}




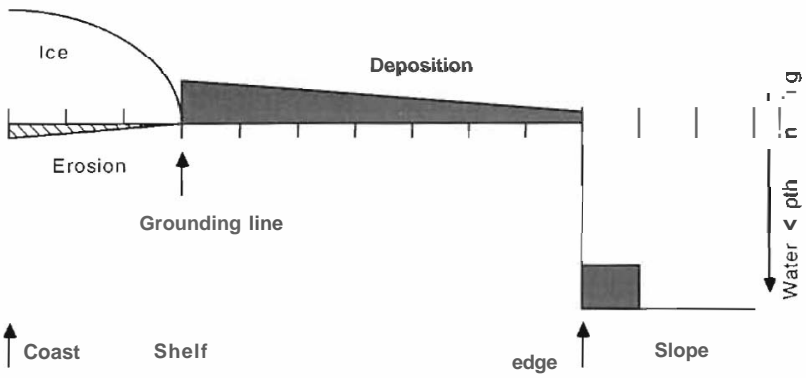

Fig. 3. Illustration of one model step. Pattern of deposition on the shelf ahead of the grounding line and erosion behind the grounding line are similar for all steps and are only a function of the distance from the grounding line. When deposition extends beyond the shelf edge, all remaining sediments fill the first slope position. When this position is filled to the level of the shelf edge at that time, it becomes part of the shelf, and the next position then begins to fill.

early from the coast to the paleo-shelf edge, and (2) flexural loading from the adjacent continental ice sheet [from ten Brink and Cooper, 1992] (Figure 4a), and during the model run, we incrementally added moderate subsidence. Total subsidence was $205 \mathrm{~m}$ at the coast and $520 \mathrm{~m}$ at the paleo-shelf edge, which for a 40 m.y. period is 5 to $13 \mathrm{~m} / \mathrm{m}$.y. This is the thermal subsidence rate of a 100 Ma passive margin. The effect of compaction was ignored because porosity of shelf glacial sediments is highly variable with depth [Barron, Larsen et al., 1989]. Compaction of slope sediments could be significant, but the slope stratigraphy is not analyzed here.

The model was generally non dimensional, having grounding line positions serve as the distance axis and units of deposition or erosion as the vertical axis. Incorporating flexural isostasy and thermal subsidence required, however, physical dimensions. Each position, therefore, approximated $10 \mathrm{~km}$ horizontally and each erosion or deposition unit approximated $5 \mathrm{~m}$ vertically, based upon thickness of Quaternary sediments recovered at Ocean Drilling Program Site 742 in Prydz Bay [Barron, Larsen, et al., 19891.

\section{RESULTS}

Our reference model (Plate lb) mimics the salient features observed on seismic-reflection profiles across the Antarctic shelf (Figure 1). The relatively deep floor of the inner shelf trough rises toward the outer shelf.
Basement of the inner shelf is eroded. The layers are thin and continuous and aggrade and prograde seaward, and there are few unconformities, which truncate the outer shelf sediments (U1-U6 in Plate lb). The layers pinch out toward the inner shelf, as observed (Figure la). Figure $4 \mathrm{~b}$ shows that the total erosion decreases toward the shelf edge, whereas deposition increases. Net erosion is generally confined to the inner shelf and net deposition to the outer shelf, as observed (e.g., Figure la). The difference between the net and total deposition indicates the degree of sedimentreworking that occurs in the model. For examples, at $\mathrm{km} 70$ along the shelf, all the deposited sediments were later eroded and deposited farther seaward; at km 120, $33 \%$ of the deposited sediments were later eroded; and at km 170, $10 \%$ were eroded.

Sea-floor morphology in the model developed gradually over many steps of the model, and attained its characteristic reverse profile only after about 20 steps of glacial advance and retreat Figure 4c). Drilling results from ODP Leg 119 show, indeed, that the early glacial deposits have accumulated in a lacustrine environment, whereas only later deposits have accumulated in deeper marine environment [Hambrey et al., 1991]. Stratigraphy and morphology in the early glacial stages have been likely affected by related eustatic changes, but, for the sake of simplicity, these factors were not considered here.

Provided that erosion occurs mainly under the grounded glacier and deposition mainly ahead of the grounding line, the model explains unconformities at the shelf edge and truncation of prograding sequences whenever the grounding line resides for several steps close to the shelf edge. This effect can be shown by constraining the grounding line to be at the shelf edge for 20 steps (Plate 2). The grounding line in the random model occasionally resides for several steps near the shelf edge, and the effect on stratal geometry is occasional unconformities (U1-U6 in Plate la). Regional erosion of the shelf can also be caused by increasing the probability with time,for the grounding line to reside near the shelf edge.

A thick sedimentary packet is generated in the middle and outer shelf when the grounding line is near the coast for several steps. This effect is shown in Plate 2, where the grounding line is kept at the coast for 10 steps. Preservation of sedimentary sequences depends, however, on subsequentlocations of the grounding line. The thin sedimentary section of the middle shelf (positions 7-12) in our reference model (Plate lb) consists of layers deposited during steps in which the grounding line is close 

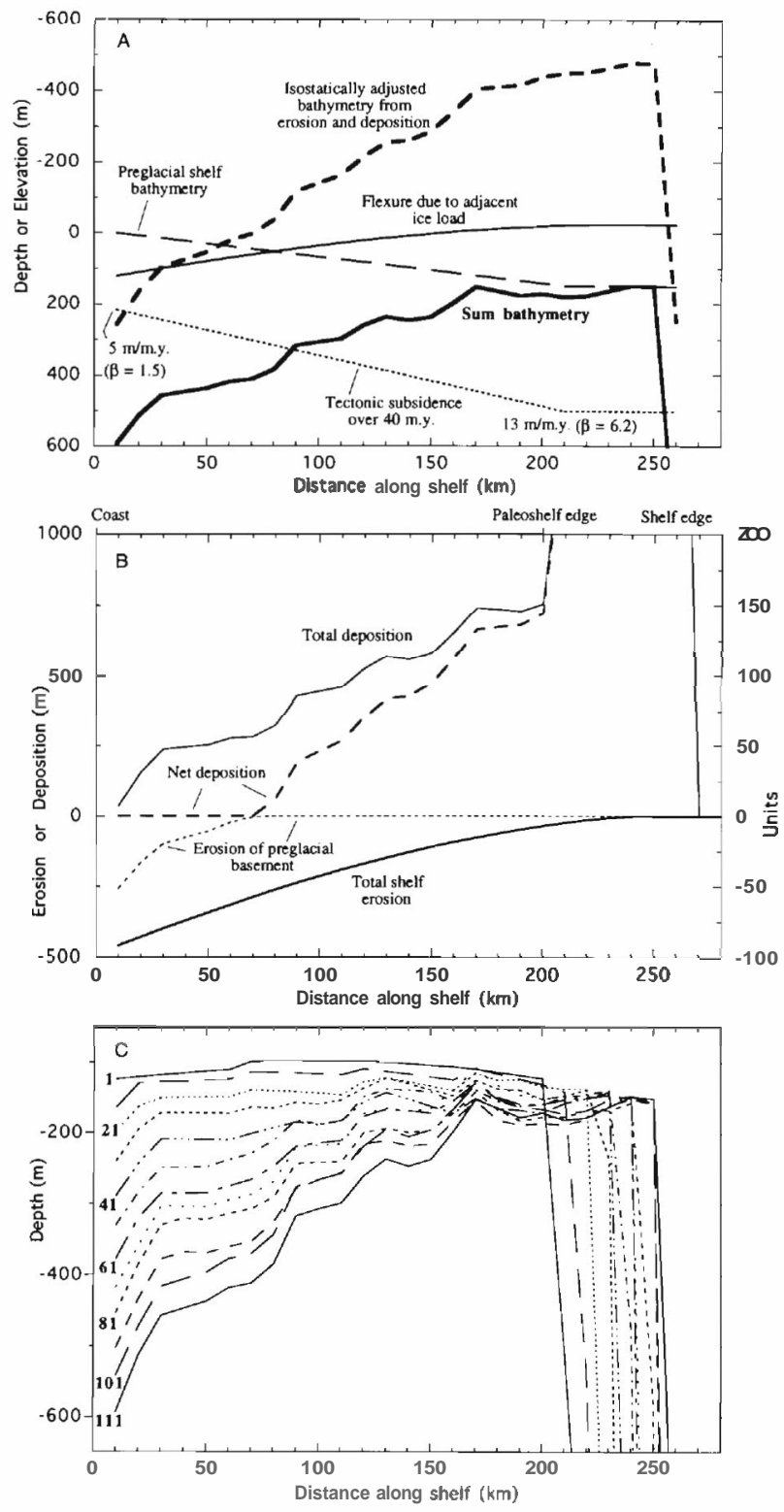

to the coast. Only partial records of glacial minima (about 8 of 25; numbers 1-8 in Plate la) are, however, preserved in the stratigraphic record of the random model; the rest are subsequently eroded.

The probability that the grounding line in our reference model (Plate lb) will occupy all shelf position is favorably skewed toward positions at the shelf edge by the fact that the shelf edge is located between position 20 (at the start of the model run) and position 25 (at the end of the model run), whereas $\mathrm{N}=35$. We can introduce a bias toward the shelf edge in a different way by defining the model as a random retreat from the shelf edge
Fig. 4. (A) Parameters of model in Plate lb. Heavy solid line - bathymetry of model in Plate $1 \mathrm{~b}$ (heavy line). Other lines - various contributions to shelf bathymetry. Isostatically adjusted bathymetry due to sediment erosion and deposition (heavy broken line) is by far the largest contribution to observed landward-dipping shelf morphology. (B) Total shelf erosion, total deposition on shelf and paleoslope, net deposition (after glacial erosion of shelf), and erosion into preglacial basement, as function of position across shelf for model in Plate $1 b$. The difference between total and net deposition equals the difference between total erosion and erosion of preglacial sediments, and represents the sediments that have been deposited and later reworked and transported. 1 vertical unit $=5 \mathrm{~m}, 1$ horizontal position $=10 \mathrm{~km}$. (C) Sea-floor morphology after the first, tenth, twentieth, etc. steps in the model. Note that the reverse morphology develops only after about 20 model steps. Preglacial bathymetry and flexural loading from adjacent ice sheet were added before the first step, and tectonic subsidence was added incrementally.

(Plate lc), rather than random advance and retreat (Plate la). This model addresses the possibility that aggradation of the shelf occurs during glacial retreat [e.g., Boulton, 1990; Bartek et al., 19911. In the random retreat scheme, the grounding line reaches the shelf edge, then retreats to a random place on the shelf, returns to the shelf edge, and then retreats again, and so on. The stratigraphies produced by these two schemes are not markedly different (cf. Plate $1 \mathrm{~b}$ and 1d).

A gradual change from progradation in the lower part of the section to aggradationin the upper part of the section is observed in the Plio-Pleistocene section of the Ross Sea (Figure 2a; Cooper et al. [1991b]; Alonso et al. [1992]), Bartek et al. [1991] interpreted this change to be due an increase in the frequency of eustatic cycles. This change is likely, however, regardless of external forcing factors. It is a consequence in our model of increasing shelf width with time by progradation, which makes the probability of grounding line positions be less skewed toward the shelf edge. For .example, in Plate lb, compare the increasing sediment thickness between successive dots, where the dots are horizontally one position apart.

\section{SENSITIVITY TO MODEL PARAMETERS}

By varying the input parameters of the model, one at a time, we can learn about their significance and the significance of some underlying assumptions (Table 1). 


\subsection{Randomness}

A random approach to ice fluctuations is a useful starting point for modeling, because we do not have direct observations of the extent of grounded ice over geological time. The random approach assumes that the grounding line often reaches only part way across the shelf. If instead we assume that the location of the grounding line always alternates between the coast and the shelf edge, the model produces a thick inner-shelf sedimentary section, which thins toward the outer shelf (Plate 3a). This has not been observed. Even if the deposition pattern is constant with distance ahead of the grounding line, instead of decreasing linearly, the resulting morphology and stratal geometry do not agree with the observations (Plate 3b). The morphology deepens seaward, there are no unconformities in the shelf stratigraphic section, and outer-shelf aggradation is limited. None of these are commonly observed. Hence, the glacial grounding line must occupy different positions across the shelf throughout time to explain the observed stratal geometries.

The probability that the grounding line occupies all shelf positions does not, however, have to be uniform. For example, as the inner shelf deepens, the grounded glacier may be less likely to terminate in the inner-shelf trough than farther seaward at the shallower part of the shelf. The width of the shelf or the pressure that drives the flowing ice may also determine how random the positions are. If the shelf is narrow or the driving pressure consistently high, the grounding line is expected reach the shelf edge often. The effects on the stratal geometry of a bias from uniform probability are shown in Plate 4. A bias in the random scheme in favor of the grounding line occupying preferentially the shelf edge was introduced into the model by increasing the number of positions, $\mathrm{N}$, beyond the shelf edge. The models show increasing progradation, decreasing aggradation, and increasing number of shelf unconformities, as the probability that the grounding line is located at the shelf edge is increased.

\subsection{Patterns of Erosion and Deposition}

Erosion must occur under the ice mass to create an inner-shelf trough, which erodes into preglacial basement and sediments (Plate 5a). The stratal geometry is only mildly sensitive to the pattern of erosion (i.e., whether erosion is constant with distance behind the grounding line or is linearly increasing).
Varying the pattern of deposition however, has a large effect on the stratal geometry. The stratal geometry produced by linearly decreasing deposition ahead of the grounding line (the reference model) produces thin continuous layers on the shelf, which pinch out toward the inner shelf (Plate 5d). A depositional pattern of constant thickness ahead of the grounding line instead of a tapered pattern results in an "offlap" relationship in the middle shelf (Plate $5 c$ ) (i.e., topset units migrate seaward as they become younger) which is generally, not observed (Figures 1 and 2; Anderson and Bartek [1992]; Cooper et al. [1991b], Larter and Barker [1989]). If the pattern of deposition decays logarithmically with distance, as observed in front of present-day temperate and subpolar Northern Hemisphere glaciers [Andrews, 19871, the layering becomes highly disconlinuous and varies in thickness over short distances on the shelf (Plate 5b). This pattern is not observed in Antarctica. We therefore, suggest that many repeated ice advances across a continental shelf act as an averaging agent that reworks recently deposited morainal banks and fans over large distances to form continuous layers.

\subsection{Changes of erosion and deposition patterns with time}

It is reasonable to assume that as the climate in Antarctica cooled, the margins passed from temperate to subpolar to polar conditions, and the sedimentary pro ${ }^{-}$ cesses and associated rates ${ }_{0} f$ deposition and erosion probably changed [Anderson and Ashley, 1991]. To il$1_{\mathrm{u}}$ strate the potential effect of changing rates and deposition patterns on the stratal geometry during the late Cenozoic, we arbitrarily doubled or halved the deposited

and eroded volume midway during the model runs (at step 56) (Plate 6a, b), and simultaneously changed the pattern of deposition (Plate $6 \mathrm{c}, \mathrm{d}$ ).

Doubling or halving the amounts of sediment $\mathrm{d}_{\text {eposi }}{ }^{-}$ tion and erosion per step has only a small effect on the stratal geometry of the simulated section relative to the reference section (compare Plate $6 \mathrm{a}, \mathrm{b}$ to Plate $1 \mathrm{~b}$ ). Layers continue to pinch out toward the inner shelf without a significant break in sedimentation. With increasing amounts of sediments deposited during half of the steps, the total thickness of aggraded and prograded sediments naturally increases. Because erosion is halved (Plate 6a, b), the glacial section extends farther toward the inner shelf.

A simultaneous change at step 56 in the amounts of sediment deposition and erosion, and in the deposition 
pattern has a larger effect on the stratigraphy. A change from a constant deposition with distance to a linearly decreasing deposition with distance, results in a regional unconformity (Plate 6d). The upper section extends farther toward the inner shelf producing an "onlap" pattern, when erosion is halved and deposition doubled in the second half of the model run (Plate $6 \mathrm{c}$ ). The opposite pattern, "offlap", is produced when erosion is halved and deposition doubled in the first half of the model run (Plate 6d).

\subsection{Isostasy and Tectonic Subsidence}

As mentioned in the introduction, the similarity in stratal geometry and morphology of different sectors of the Antarctic shelf is striking, in light of their different tectonic and thermal histories. Here we investigate the effects on the models of changing the isostatic and tectonic subsidence. Plate 7 compares the bathymetry and stratal geometries of two models, which are similar in all their parameters, except the type of isostatic compensation used in the model (Airy vs. flexure). Flexure causes more progradation and less aggradation relative to a model using Airy compensation because the accommodation space for slope sediments is smaller in the flexure model than in the Airy model (compare Plate 7a to $7 \mathrm{~b})$. Sediments in the flexure model extend farther toward the inner shelf than in the Airy model, and the bathymetric profile bows down from the mid-shelf toward the shelf edge in a model with flexural isostasy, due to the weight of the slope sediments. Overall, however, the differences in the stratal geometry between the Airy and the flexural model are not significant (insets in Plate 7a, b).

The effect of tectonic subsidence on the sea morphology is significant (Plate 7). Doubling the amount of subsidence relative to the reference model (Plate lb) results in a deeper bathymetry, which is fairly flat across the shelf (Plate 7c). A deep and fairly flat bathymetry is observed in several Antarctic Peninsula profiles (e.g., Figure 2b; Anderson et al. [1990]). The bathymetry across the entire shelf deepens at a fairly equal "rate" (or step increment)(Plate 7d) in contrast to the evolution of the bathymetry in the reference model (Figure 4c). The shelf profile is tilted toward the inner shelf, despite the large difference in the total tectonic subsidence between the coast $(410 \mathrm{~m})$ and the shelf edge $(1040 \mathrm{~m})$. This tilt, however, only develops after step 51 . The stratal geometry of the shelf is not affected by the increased subsidence (Plate 7c), because the underlying assumption in our model is that deposition and erosion are independent of water depth and the slope of the shelf floor.

\section{SEA LEVEL, GLOBAL ICE VOLUME, AND THE LOCATION OF THE GROUNDING LINE}

\subsection{Sea-Level Curve and Constant Sediment Transport}

The locations of the grounding line were so far generated by a random number series on the computer because of the absence of direct observations. It has been suggested that glacial advances are correlated with lowering of global sea level and glacial retreat with rising sea level [e.g., Boulton, 1990; Bartek et al., 1991] because, although the shelf may be overdeepened, sea-level change may shift the grounding (or pinning) points of the ice. Pleistocene sea-level variations are believed to have been mainly the result of Northern Hemisphere glaciations and deglaciations, but the relationship between global sea-level variations and the Antarctic icesheet fluctuations is not clear [e.g., Mix and Ruddirnan, 1985]. To investigate the influence of sea-level fluctuations on the stratigraphy of the Antarctic shelf, we linearly correlated the locations of the grounding line with the global sea-level curve for the last $30 \mathrm{Ma}$ (Plate 8a) [Haq et al., 19881. We assumed that the minimum sea level during this period corresponded to the grounding line at position 35 (beyond the shelf edge, as in the random model) and that the maximum sea level during the period corresponded to the grounding line at the coast. These assumptions were made to facilitate the comparison with the results from the random-scheme models. The sea-level model was also used to investigate the assumption of a constant glacial transport rate (erosion and deposition), instead of a constant volume per model step (the assumption used throughout this paper). The volume of sediments per step was proportional to the duration of sea-level rise or fall.

The stratigraphic record, generated by the correlation of sea-level changes with the locations of the grounding line, produces onlap onto the inner shelf in the early fluctuations (30-25 Ma) followed by "offlap" (i.e., topset units migrate seaward in progressively younger units) during the rest of the fluctuations (Plate 8b). The "offlap" pattern is generally not observed across the Antarctic shelf (e.g., Figures 1 and 2; Larter and Barker, 1989]; Anderson et al. [1990]; Cooper et al. [1991a, 19931). The "onlap" and "offlap" are due to the longterm sea-level trend (rise in the first 5 m.y. followed by fall in the remaining period, Plate 8a). In addition, layer thicknesses vary considerably throughout the model section, and some layers actually thicken landward, both of which are not observed in the seismic data (e.g., Figures 
1 and 2). However, Haq et al. [1988] sea-level curve is not sufficiently precise or detailed (only 42 steps during the last $30 \mathrm{Ma}$ ), hence any conclusions from this model regarding transport rate or correlation with sea level should be regarded with caution.

Bartek et al. [1991] attributed the change in the PlioPleistocene section of the Ross Sea from progradation in the lower part of the section to aggradation in the upper part of the section (Figure 2; Cooper et al. [1991b]; Alonso et al. [1992]) to increased frequency of eustatic cycles. They reasoned that, because the longevity of ice grounding events diminished, the delivery of sediments to the outer shelf and slope significantly decreased, and therefore seaward progradation of the shelf greatly diminished. The transport rate in our model (Plate $8 b$ ) is constant, and therefore, a smaller volume of transport is associated with shorter grounding events. Nevertheless, there is no pronounced change from progradation to aggradation relative to models with constant rate of grounding line fluctuations (c.f., Plate 1b)

\subsection{The Oxygen Isotope Record}

A more precise and detailed record of changes in the global ice volume with time is represented by the oxygen isotope anomaly $\left(\delta^{18} \mathrm{O}\right)$ [Imbrie et al., 19841. In the remainder of this section, we discuss models in which the location of the grounding line is linearly correlated with the $\delta^{18} \mathrm{O}$ record. The choice of linear relationship between the location of the grounding line and the amplitude of $\delta^{18} \mathrm{O}$ is justified as a first order approximation because the observed relationship between the volumes and areas the of ice sheets and ice caps is only weakly non-linear $\left(\right.$ Volume $=(\text { Area/10 })^{1.23} ;$ Paterson [1994], p. 247). We assume that minimum $\delta^{18} \mathrm{O}$ values during this period (which are close to today's value) correlate with a grounding-line position at the coast line, and the maximum $\delta^{18} \mathrm{O}$ values correspond to position 35 (beyond the shelf edge, as in the random scheme).

Detailed records, which represent the global shallow and deep water $\delta^{18} \mathrm{O}$ variations, are available, respectively, for the last 0.8 m.y. at 2 ky [SPECMAP; Imbrie et al., 1984] and for the last 5 m.y. at 4 ky intervals [Mix et al., in press]. Both works demonstrated that the majority of the spectral power in the $\delta^{18} \mathrm{O}$ record is concentrated at periods which correspond to orbital forcing (41 and $100 \mathrm{ky}$ ). We use these records to draw different conclusions regarding the relationship between grounding line fluctuations and the stratal geometry, but we do not imply that the entire Antarctic shelf stratigraphy developed during either the last 0.8 m.y. or the last 5 m.y. An ice sheet existed on the outer continental shelf of Prydz Bay as early as $36 \mathrm{Ma}$, [Barron, Larsen et al., 1989].

\subsection{Gradual Advances and Retreats in the Stratigraphic Record}

The $\delta^{18} \mathrm{O}$ record for the last $0.8 \mathrm{~m}$.y. was used to model a stratal geometry, formed by gradual advances or retreats of the grounding line. The record was resampled to 111 points, one every $7.1 \mathrm{ky}$, to facilitate comparison with the random-scheme models, which have the same number of steps. The shape of the record was minimally affected by the resampling. Because of the dominance of the relatively long orbital periods, the $\delta^{18} \mathrm{O}$-based model is composed of low frequency cycles of advance and retreat, each of which is composed of several steps (Plate 8c), in contrast to frequent advances and retreats across the shelf in the random-scheme models (Plate la). Because unconformities occur at the shelf edge and prograded sequences truncated there, when the grounding line resides for several steps consistently close to the shelf edge (e.g., Plate 2), all major maxima in the $\delta^{18} \mathrm{O}$ record (i.e., glacial maxima) are associated with outer-shelf unconformities. As a result, unconformities at the shelf edge are more periodic and truncate prograding sequences more often in the $\delta^{18} \mathrm{O}$-based model (Plate 8d) than in the random model (Plate lb). Periodic outer-shelf unconformities are observed in some seismic profiles' (e.g., Figure 2a). Because of the gradual advances and retreats in the $\delta^{18} \mathrm{O}$-based model, all major sediment packets from glacial minima are preserved on the middle shelf (Plate 8d). In comparison, only about 8 of 25 sedimentary packets deposited during glacial minima are preserved in the stratigraphic record of the random model; the rest have been eroded (Plate 1b). All the major sequences in Figure 2a extend inland, as modeled in Plate 8d. Hence, we suggest that erosion and deposition during gradual advances and retreat may occur across some continental shelves.

\subsection{Oxygen Isotope and the Extent of Grounded Ice}

We used the $\delta^{18} \mathrm{O}$ record for the last $5 \mathrm{~m}$.y. to investigate whether the amplitude of the $\delta^{18} \mathrm{O}$ record, which presumably represents the global ice extent, is linearly correlated with the location of the grounding line on the Antarctic shelf. The $\delta^{18} \mathrm{O}$ record for the last 5 m.y. [Mixet $a l$. , in press] was resampled by 300 points (one 

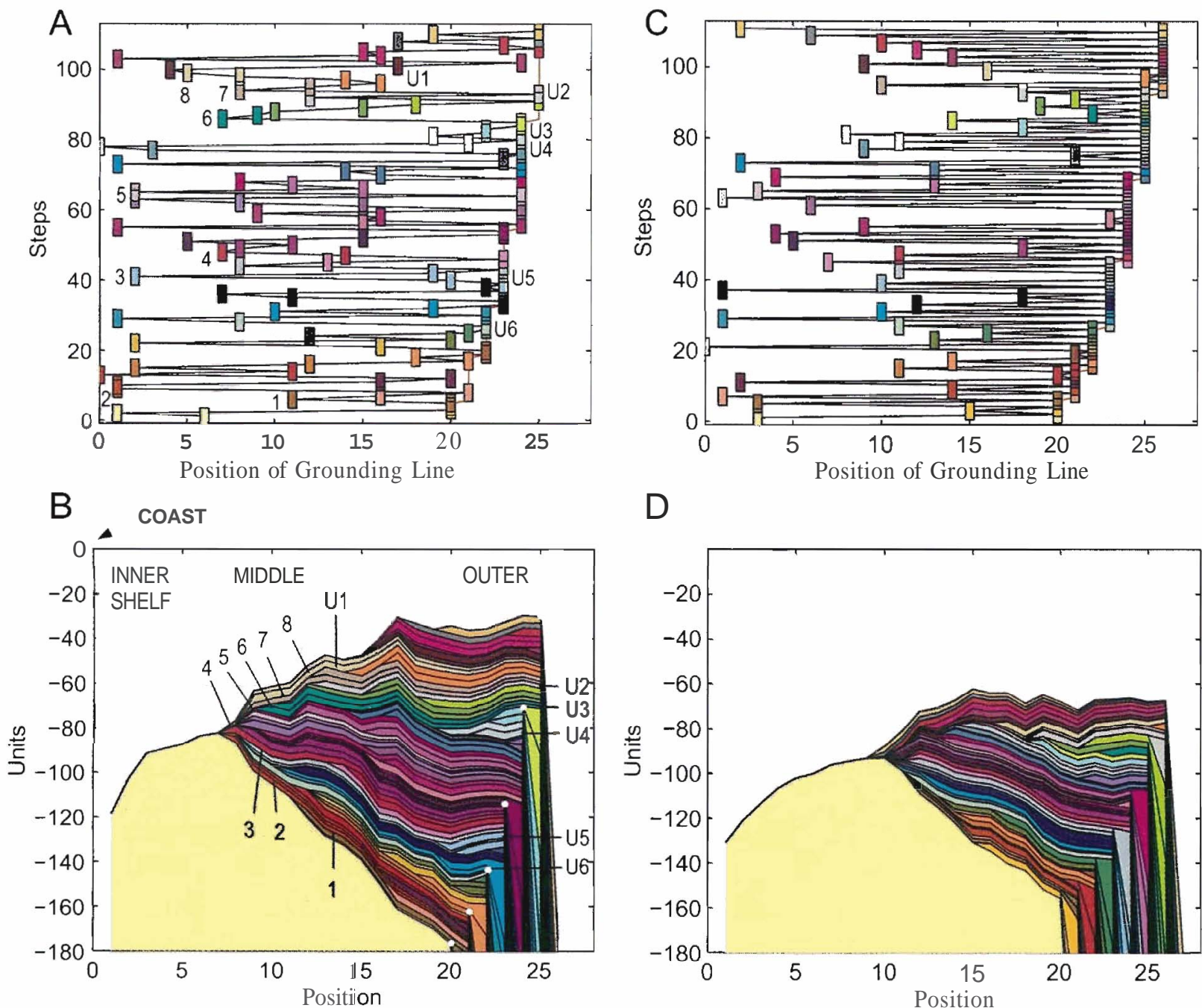

D

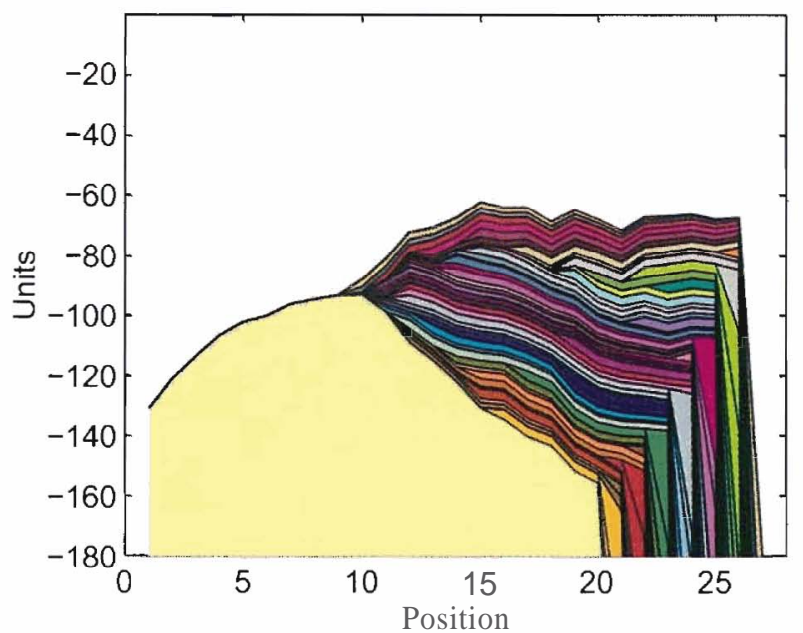

Plate 1. (A) Positions of the grounding line (squares) and the shelf edge (red line) in each step of the model run. Model had 111 steps. Positions were generated by uniform random number series. (B) Stratigraphic section generated by deposition and erosion relative to the positions of the grounding line in A and adjusted for Airy isostasy. In each step, deposition is 3.5 units $(17.5 \mathrm{~m})$ at grounding line linearly decreasing to 0.5 units $(2.5 \mathrm{~m}) 22$ positions $(220 \mathrm{~km})$ ahead of grounding line, and erosion is increasing from no erosion at grounding line to 2 units $(10 \mathrm{~m}) 22$ positions $(220 \mathrm{~km})$ behind the grounding line (i.e., total amount of deposition is larger than amount of erosion). Colors of layers correspond to colors of steps in which they were deposited. White dots - Positions of shelf edge through time. Note the upward change from a more prograding to a more aggrading section. U1-U6 - Unconformities (in B) and their corresponding glacial maxima (in A). 1-8 - Labels for preserved layers in the middle shelf (in B) and their corresponding glacial minima (in A). (C) and (D) - Same as A and B, respectively, but in this case, grounding line is at the shelf edge at even steps, and at random positions across the shelf at odd steps. This model was designed to test the hypothesis that aggradation occurs mainly during retreat and progradation mainly during advance [Boulton, 1990]. Note large vertical exaggeration $(\sim 200: 1)$ to facilitate identification of topset stratal geometry. 

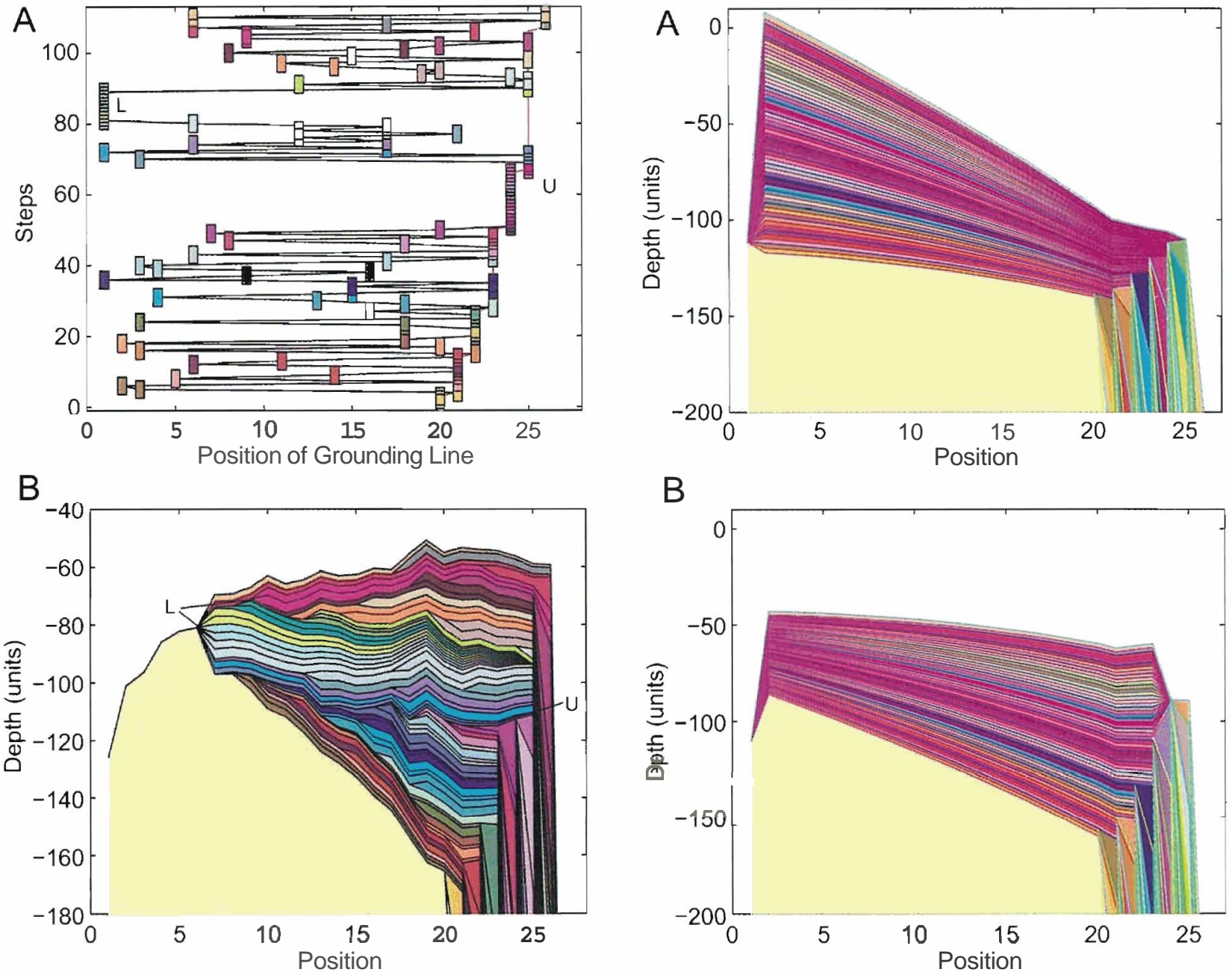

Plate 2. (A) Model in which positions of the grounding line (squares) and the shelf edge (red line) were generated by uniform random number series (similar to Plate la), except that the grounding line was constrained to be at the shelf edge during steps $\mathbf{5 0 - 7 0}$ and at the coast during steps 80-90. (B) Stratigraphic section for the model in A. A regional unconformity (U) forms when the grounding line is at the shelf edge for 20 steps, and a thick sequence (L) is preserved in the middle shelf when the grounding line is at the coast for 10 steps. Colors and vertical exaggeration as in Plate 1.

Plate 3. (A) Stratigraphy generated by a model in which the position of the grounding line alternates only between the coast and the shelf edge, and never occupies intermediate positions. Deposition and erosion patterns are as in Plate lb. (B) Same as A, except that deposition pattern is constant with distance ahead of grounding line (2 units) instead of linearly decreasing. Total volume deposited per step is similar to A. 

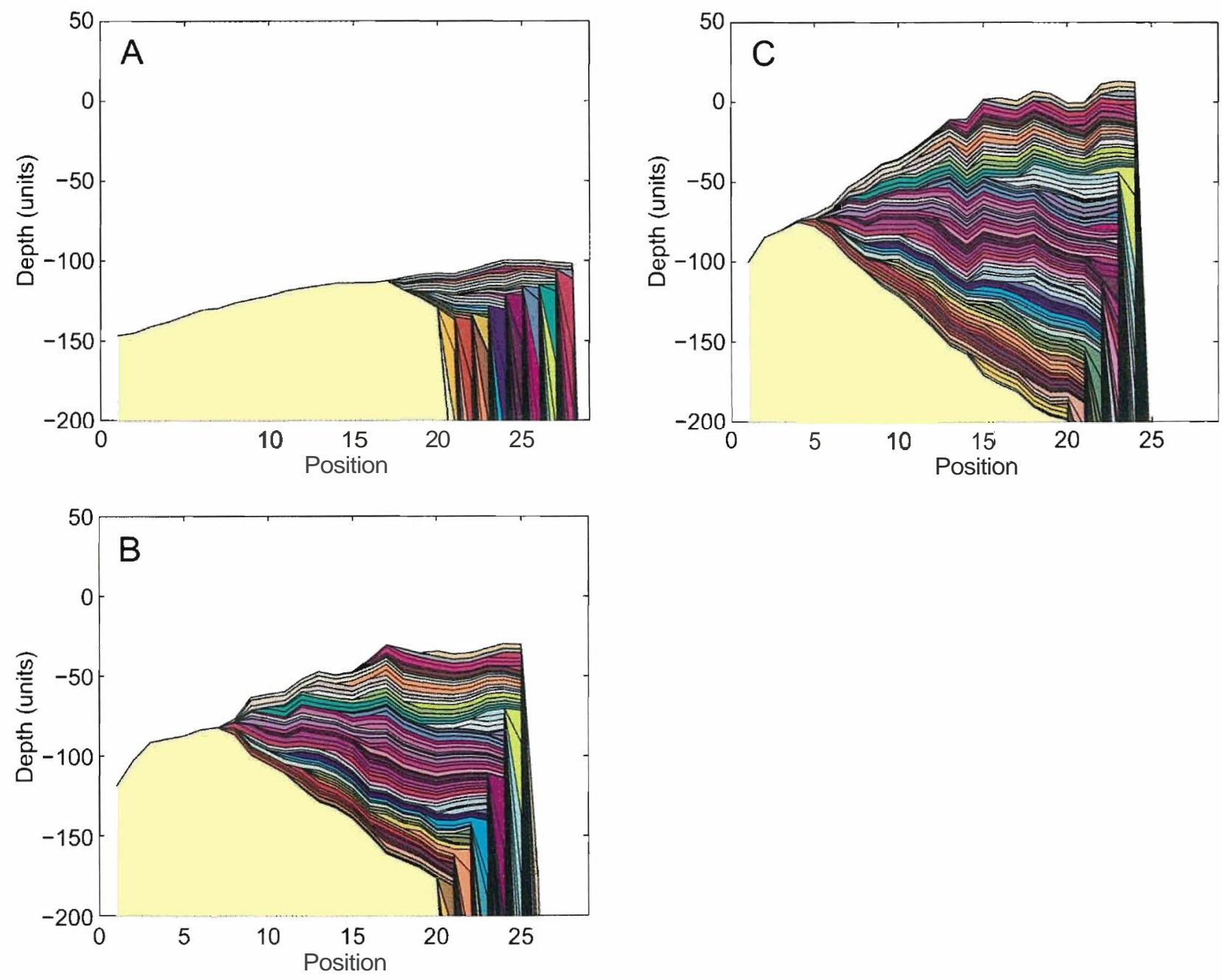

Plate 4. Comparison of the stratigraphy among three models in which the probability that the grounding line will be at the shelf edge is (A) very high, (B) slightly higher than anywhere else across the shelf, and $(\mathrm{C})$ the same as anywhere else across the shelf. The bias from uniform probability was introduced by having $\mathrm{N}$, the number of possible positions, be larger than the shelf width, because, for all positions that fall beyond the shelf edge, the grounding line occupies the shelf edge. (A) $\mathrm{N}=100$, (B) $\mathrm{N}=35$ (same as in Plate la), and (C) $\mathrm{N}=$ shelf width at that step. Shelf is 20 positions wide at the start of all model runs. The probability that the grounding line will preferentially reach the shelf edge likely depends on the shelf width, and the ice driving pressure, and possibly on the depth of the inner-shelf trough. 

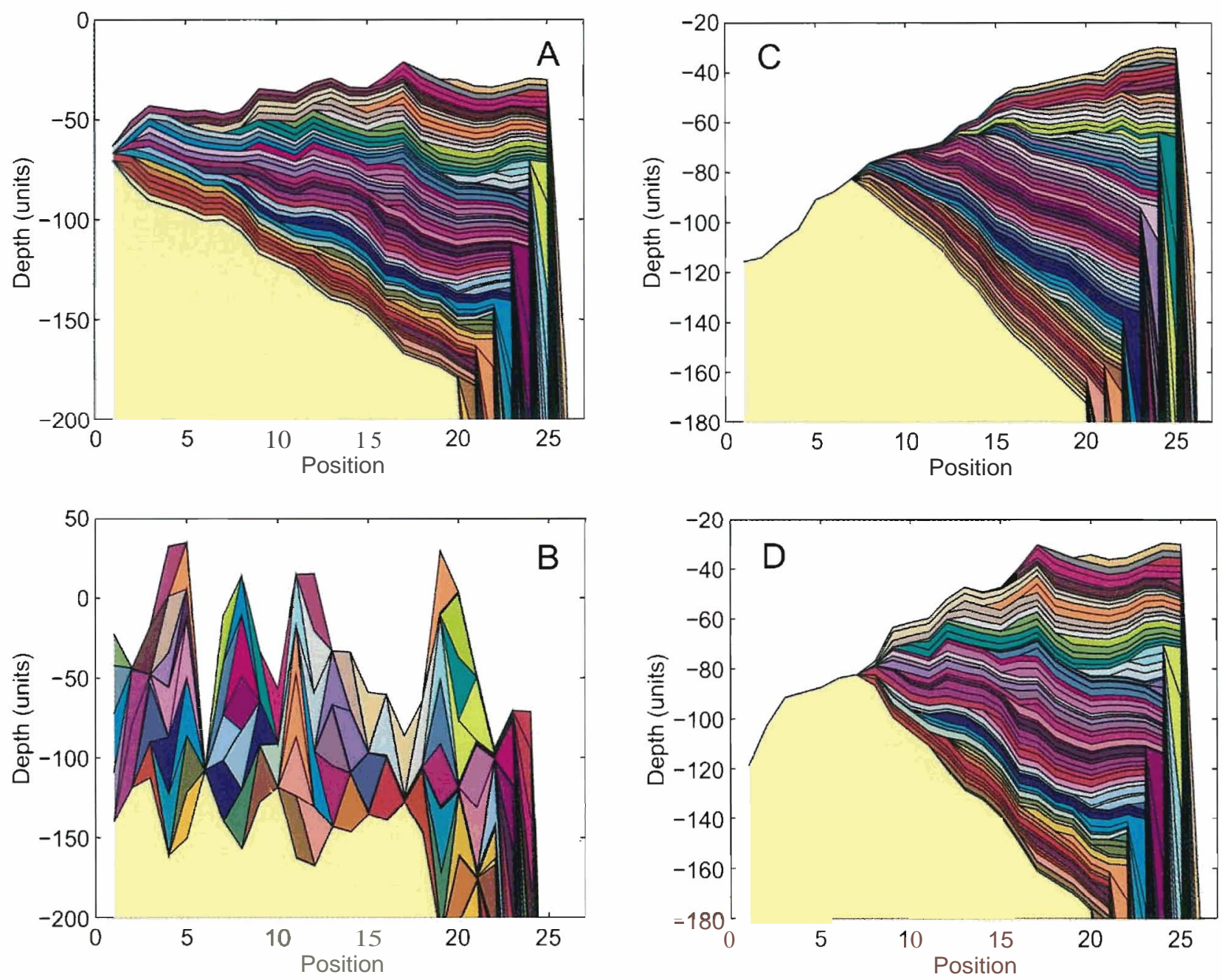

Plate 5. Results of models in which erosion and deposition patterns were modified. (A) Model without subglacial erosion. Note the preservation of glacial sediments on the inner shelf in the model without erosion, and their complete removal in the model with erosion (Plate lb). The latter is generally observed, suggesting subglacial erosion must occur. (B) Model with logarithmic decay of deposition with distance from the grounding line [Andrews, 1987]. Majority of sediments were deposited one position $(10 \mathrm{~km})$ ahead of the grounding line. $(\boldsymbol{C})$ Model with constant deposition pattern of 2 units $(10 \mathrm{~m})$ thick over 22 positions $(220 \mathrm{~km})$ ahead of the grounding line. (D) Model identical to Plate $1 \mathrm{~b}$ (deposition decreases linearly from 3.5 units $(17.5 \mathrm{~m})$ at the grounding line to 0.5 units $(2.5 \mathrm{~m}) 22$ positions $(220 \mathrm{~km})$ ahead). Total deposited volume was similar for B, C, and D. 

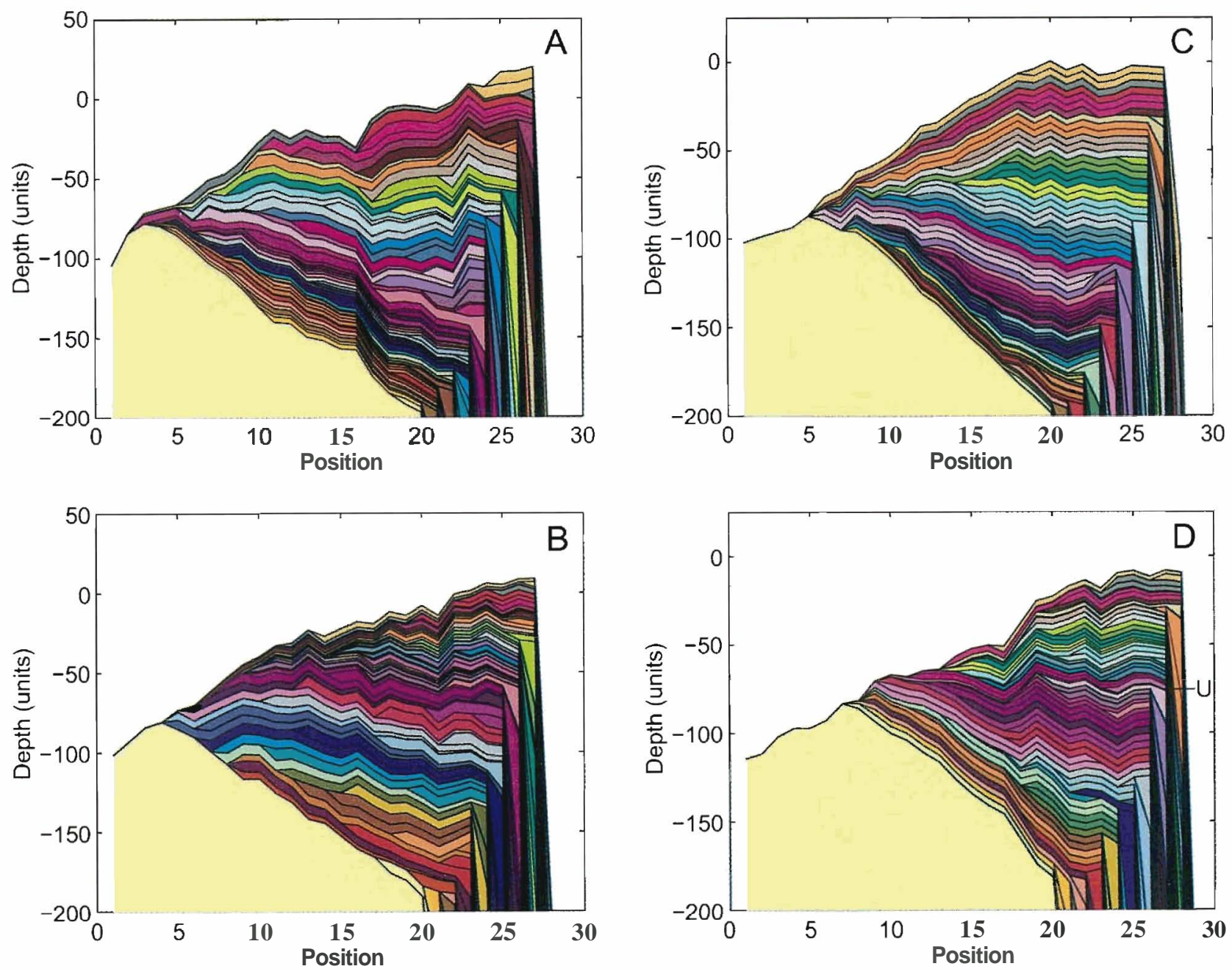

Plate 6. Models in which the volume and pattern of deposited and eroded sediments changed midway through the model run (at step 56). (A) Model identical to Plate $\mathbf{1 b}$ during steps 1-55, and with twice the depositional volume and half of the erosional volume as those in Plate $\mathbf{~} \mathbf{b}$ during steps 56-111. (B) Model in which deposition was doubled in volume and erosion was halved during steps 1-55, and parameters were similar to Plate $\mathbf{1 b}$ during steps 56-111. Pattern of doubled deposition was $\mathbf{7 . 5}$ units $(37.5 \mathrm{~m})$ at the grounding line linearly decreasing to $\mathbf{0 . 5}$ unit 22 positions $(220 \mathrm{~km})$ ahead. Pattern of halved erosion was 0 units at the grounding line linearly increasing to 1 unit $(\mathbf{5} \mathrm{m}) \mathbf{2 2}$ positions $(\mathbf{2 2 0} \mathrm{km})$ inland. (C) and (D) - Same as (A) and (B) respectively, except that whenever deposition was doubled, its pattern was a constant 4 units $(\mathbf{2 0} \mathrm{m})$ thick over 22 positions $(\mathbf{2 2 0} \mathrm{km})$ ahead of the grounding line. U - Unconformity at step $\mathbf{5 6 .}$ 

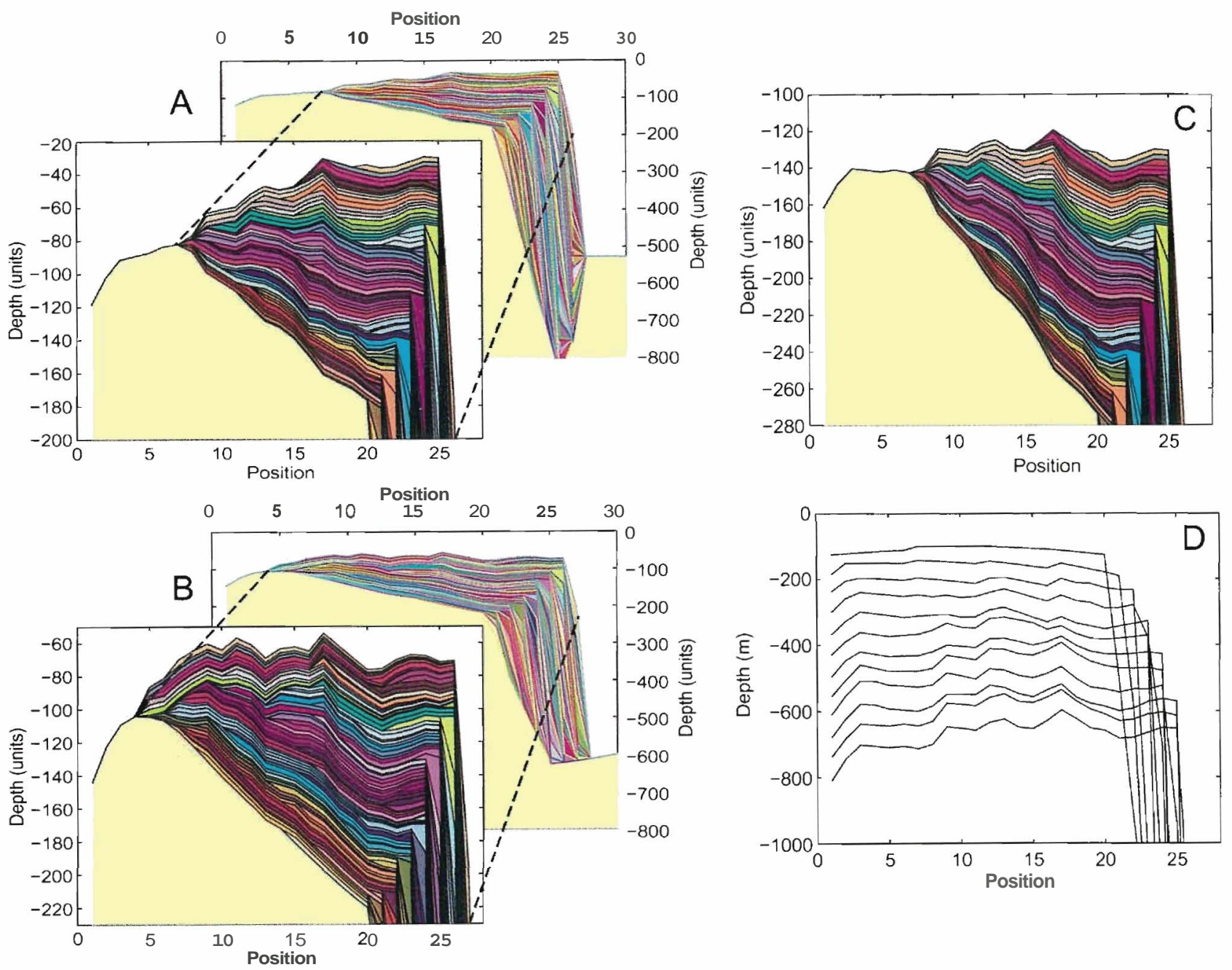

Plate 7. (A) Reference model (similar to Plate la) in which deposition (loading) and erosion (unloading) were compensated by Airy isostasy. (B) model in which loading and unloading were compensated by a flexural model with an elastic thickness (Te) of $25 \mathrm{~km}$. Insets - Detailed stratigraphic sections for the two models. (C) Model similar to (A) except that the amount of subsidence was double that of (A). (D) Sea-floor morphology after the first, tenth, twentieth, etc. steps for model in (C). Unlike Figure 4, reverse morphology develops only after 51 model steps, and subsidence proceeds at almost equal rate across the shelf. 

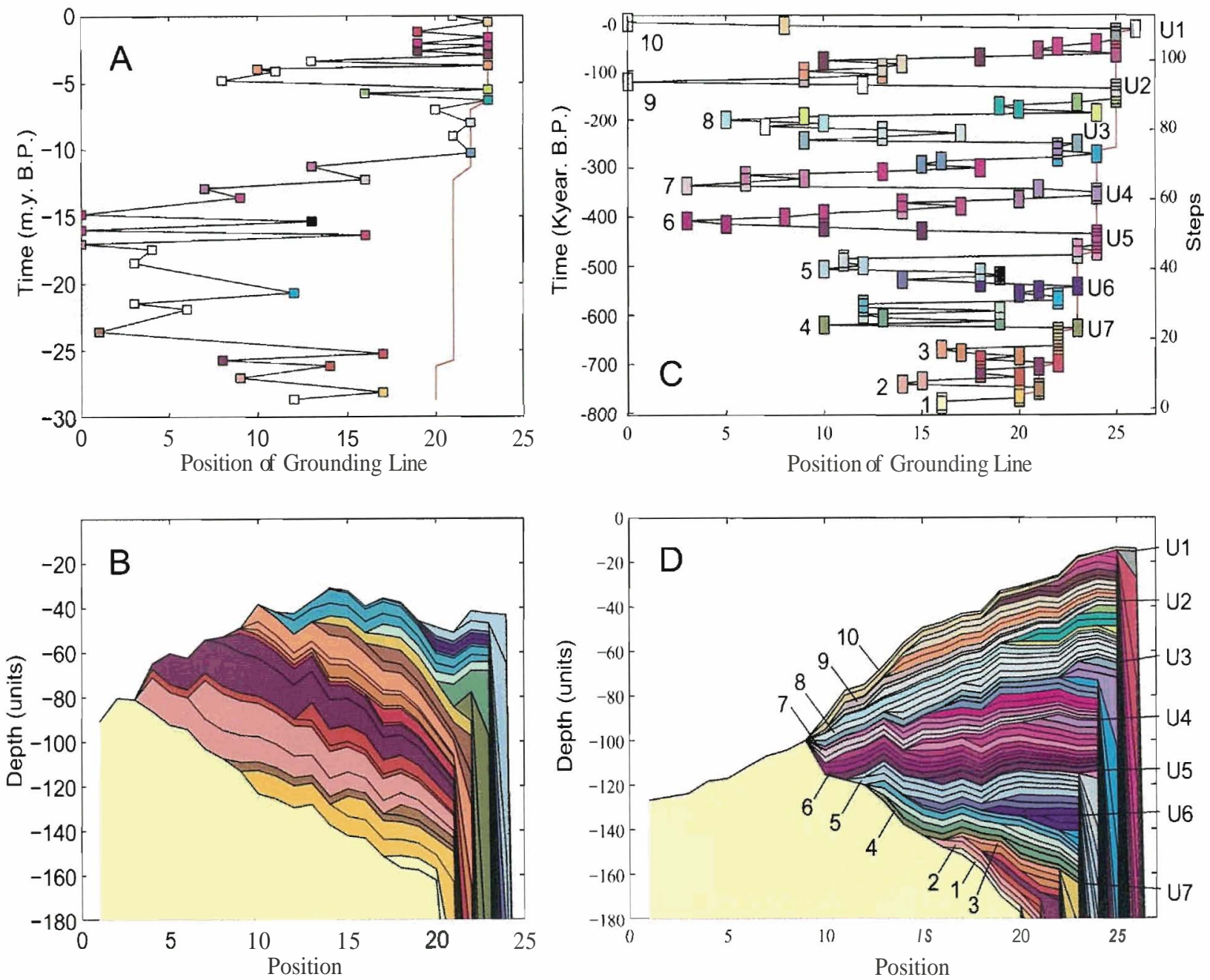

Plate 8. (A) Positions of grounding line (squares) and shelf edge (red line) in each step of the model run. Positions were linearly correlated with sea-level curve during the last 30 m.y. [ Haq ef al., 1988], with minimurn sea level corresponding to the coast and the maximum sea level to position 35 (beyond shelf edge). Model had 42 steps of varying duration. (B) Stratigraphic section generated by deposition and erosion relative to grounding line positions in (A). Transport rate was kept constant, hence the volume of eroded and deposited sediments depended on the duration of model step. Total volume was scaled to generate a section with comparable thickness to Plate lb. (C) Positions of grounding line (squares) and shelf edge (red line) in each step of the model run. Positions were linearly correlated with resampled oxygen isotope record for the last $0.8 \mathrm{~m} . \mathrm{y}$. [Imbrie et al., 1984] with minimum $\delta^{18} \mathrm{O}$ at position 0 and maximum at position 35. Model had 111 steps. (D) Stratigraphic section generated by deposition and erosion relative to grounding line positions in (C). Model shows that if there are several phases of deposition and erosion during gradual advance and retreat, then the stratigraphy should include periodic and numerous unconformities, and preserve all glacial minima. U1-U7 Unconformities. 1-10 - Labels for preserved layers. Depositional and erosional patterns and isostatic compensation for both (B) and (D) are similar to these in Plate lb. Colors and vertical exaggeration are as in Plate 1. 

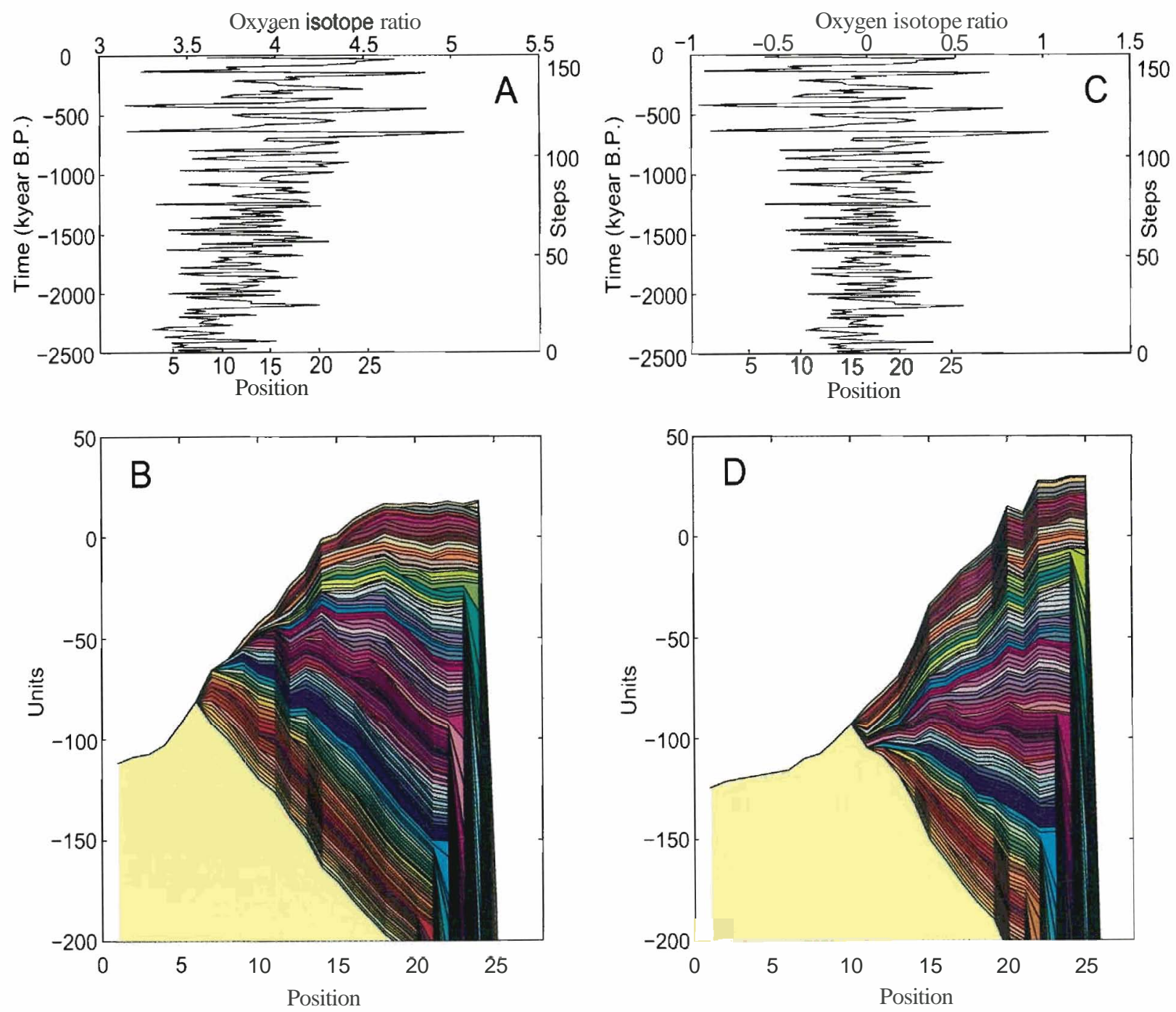

Plate 9. (A) Oxygen isotope record $\left(\delta^{18} \mathrm{O}\right)$ for the last $2.5 \mathrm{Ma}$ [Mixet al., in press] resampled by 150 steps at $16.6 \mathrm{ky}$ per step. (B) Stratigraphic section generated by deposition and erosion relative to grounding line positions, which were linearly correlated with $\delta^{18} \mathrm{O}$ record in $(\mathrm{A})$. (C) - Same as (A) after removing a linear trend from the record. The trend represents a long-term cooling of the oceans. (D) Stratigraphic section generated by deposition and erosion relative to grounding line positions, which were linearly correlated with the $\delta^{18} \mathrm{O}$ record in (C). Depositional and erosional patterns and isostatic compensation for both (B) and (D) are similar to those in Plate $1 \mathrm{~b}$. Colors and vertical exaggeration are as in Plate 1. 
every $16.6 \mathrm{ky}$ ) to keep the number of model steps small while including the dominant 41 and $100 \mathrm{ky}$ orbital periodicities. We present here models based on the oxygen isotope record for only the last $2.5 \mathrm{~m}$.y. (150 points), because the isotope ratio increased considerably between 2.8 and 3.2 Ma [Mix et al., in press].

The resampled $\delta^{18} \mathrm{O}$ record generally fluctuates back and forth every step or two, similar to the fluctuations generated by the random models (Plate $9 \mathrm{a}, \mathrm{c}$ ), but it has a long-term trend (Plate 9a), which is interpreted as gradual cooling toward the Present In addition, the amplitude of fluctuations increased significantly since 0.8 Ma because of the recurrence of vast ice sheets in the Northern Hemisphere (Plate 9a). The long-term cooling trend is responsible for the "offlap" relationship in the model (i.e., topset units migrate seaward as they become younger) because the location of the grounding line gradually moved seaward (Plate 9d). The sea-level model shows a similar "offlap" relationship for the last 25 m.y. By removing a linear trend from the $\delta^{18} \mathrm{O}$ record (Plate 9c), the "offlap" relationship disappears (Plate 9d). The increased amplitude of the $\boldsymbol{\delta}^{18} \mathrm{O}$ fluctuations post $0.8 \mathrm{Ma}$, causes the sea-floor morphology to be concave down (Plate 9d), rather than up, because prior to $0.8 \mathrm{Ma}$ the grounding line fluctuated around positions 10-15 without reaching either the shelf edge or the coast.

Figures 1 and 2 and many other published records [e.g., Larter and Barker, 1989; Anderson et al., 1990; Cooper et al., 1991a; Cooper et al., 19931 do not show seaward migration of topset units up-section in the midshelf and concave-down shelf morphology, suggesting that there is no simple relationship between the $\delta^{18} \mathrm{O}$ record and the location of the grounding line. The inferred lack of simple relationship can be explained in several ways: (1) the grounding-linefluctuations are in phase with global ice-volume changes, but the amplitude of the grounding-line fluctuationsis determined by other factors, (2) the locations of the local grounding lines are independent of Antarctic ice-volume changes and are unpredictable, or (3) Antarctic ice-volume fluctuations are unrelated to the global $\delta^{18} \mathrm{O}$.

\section{COMPARISON TO OBSERVATIONS}

Several regional stratigraphic analyses for various sectors of the Antarctic shelf have been published in recent years [e.g., Cooper et al., 1991b; Alonso et al., 1992; Anderson et al., 1992, Pope and Anderson, 1992, Larter and Cunningham, 1993; ANTOSTRAT, This volume]. Here, we highlight some of the observations and inferences derived from these observations, which are in agreement with some of our modeling assumptions and conclusions.

1. Isopach maps of Plio-Pleistocene sediments in the Eastern basin of the Ross Sea show decreasing thickness inland from the shelf edge (Figures $2 \mathrm{a}$ and 5a; ANTOSTRAT, This volume). For example, sediment thickness is $700 \mathrm{~m}$ at the shelf edge and $25 \mathrm{~m}$ at DSDP Site 272, $150 \mathrm{~km}$ inland (Figure 2a). In addition, much of the middle and upper Miocene sections at Site 272 is missing, presumably due to glacial erosion [Anderson and Bartek, 19921.

2. Plio-Pleistoceneseismic units in the Ross Sea are separated by continuous smooth high-amplitudereflectors interpreted as erosional surfaces [Alonso et $a \boldsymbol{l}$., 19921. Individual reflectors are traceable over distances of many tens of $\mathrm{km}$ and vary only slightly in thickness.

3. Although sedimentary thickness varies along strike, implying 3-D variations in sediment transport within and outside glacial troughs, the characteristic increase in sediment thickness toward the shelf edge is similar both within and outside the troughs (Figure 5a; Alonso et al. [1992]). Variations in thickness within a 115-km-wide section of the Antarctic Peninsula shelf appear to be small [Larter and Cunningham, 1993], suggesting, that at least locally within glacial troughs and banks, our 2-D approach is a good first-order approximation for modeling dip lines.

4. Evidence for terrestrial source of some of the glacial sediments on the continental shelf include glacial sediments off the George V coast of East Antarctica, which can be correlated with rock exposures on land and diamicton on the Weddell Sea and Marguerite Bay (the Antarctic Peninsula) continental shelves, which can be correlated with continental sources in those regions [Anderson et al., 1992].

5. Based on the lack of similarity between the stratal geometry generated by logarithmic deposition (Plate 5b) and observations from Antarctic shleves, we suggest that many episodic ice advances across a continental shelf acted as an averaging agent that reworked morainal banks and fans over large distances to form continuous layers. However, thin and spatially extensive layers can be an original feature if shelf sediments are primarily deposited from beneath a grounded ice sheet as it "lifts off" during glacial retreat [e.g., Boulton, 1990; Bartek et al., 1991], or if the glacial sediments are deposited by normal marine processes, as is the case for the present deposition pattern on Antarctic shelves [Domack et al., 1991; Harden et al., 19921. We 

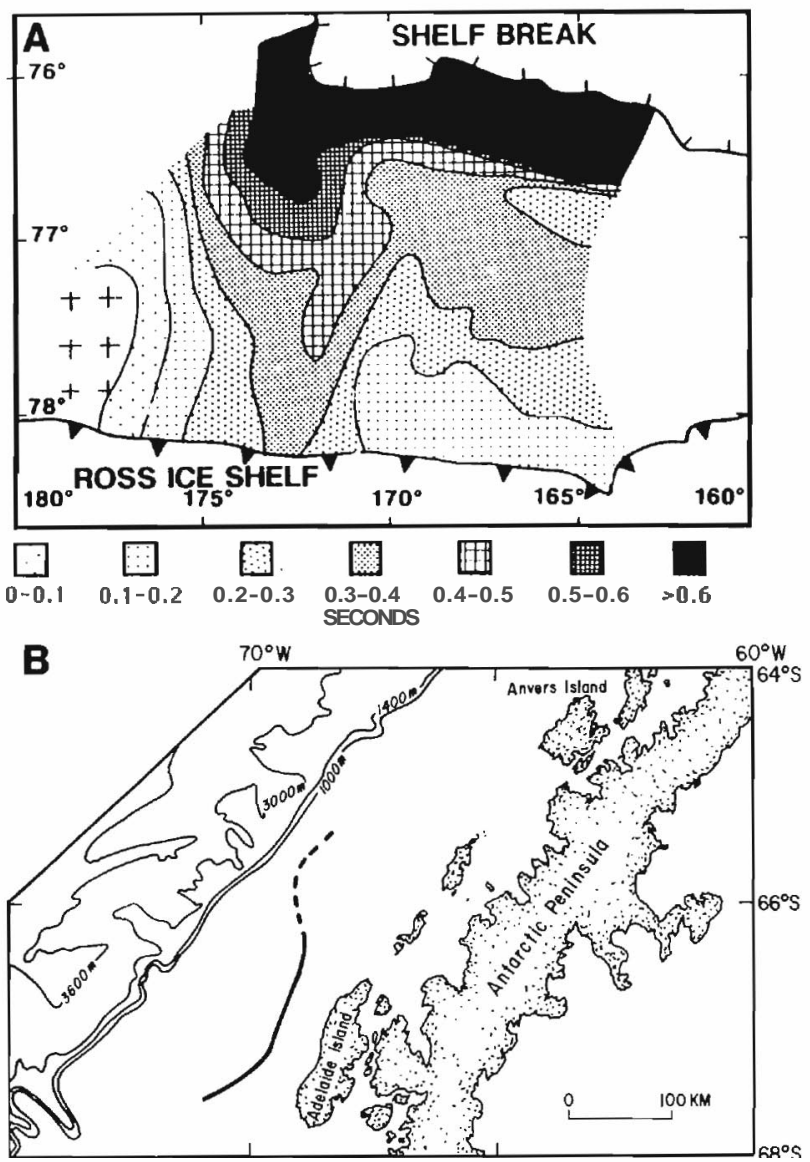

Fig. 5. (A) Isopach map of Plio-Pleistocene sediments in the Eastern basin of the Ross Sea [after Alonso et al., 1992]. ( B ) Proposed location of grounding line during the last glacial maximum (solid line) at the Antarctic Peninsula shelf [after Pope and Anderson, 1992].

favor the reworking hypothesis because (1) sediment cores collected in Prydz Bay [Barron, Larsen, et $a l$, 1989] indicate that the sediments are highly reworked, (2) diamictons from the central and eastern Ross Sea, hundreds of $\mathrm{km}$ from the present grounding line, display only subtle petrographic variations, leading Anderson $\boldsymbol{e t}$ al. [1992] to conclude that tills on the outer shelf have been transported great distances and recycled numerous times, and (3) because the Antarctic Peninsula shelf was probably under subpolar glacial conditions throughout much of its past [Anderson and Ashley, 1991], and therefore, may have had logarithmic deposition pattern similar to Northern Hemisphere observations, yet its stratal geometry (e.g., Figures $1 b$ and $2 b$ ) is unlike that in Plate 5b.
6. Reconstruction of the last glacial maximum off Adelaide Island in the Antarctic Peninsula shows that a grounded marine ice sheet reached only the inner shelf just beyond the inner trough (Figure 5b). A linear correlation between the grounding line location and the global sea-level curve or the $\delta^{18} \mathrm{O}$ record would put the grounding line at the shelf edge. In addition, a subglacial delta, deposited after the end of the last glacial maximum, was recently identified at the outer Antarctic Peninsula shelf [Larter and Vanneste, 19951. These observations indicate that the relationship between the location of the grounding line and the global sea level or $\delta^{18} \mathrm{O}$ records is not simple, as is also noted by our model results.

Although this paper is concerned with the Antarctic shelf, several Northern Hemisphere shelves yield observations that are in agreement with our models. For example, glacial activity on the southeast Greenland shelf, which has a morphology similar to the Antarctic shelf, was traced back to $7 \mathrm{Ma}$, and is thought to be the result of numerous ice advances [Larsen et al., 19941. One of the Northern Hemisphere shelf areas that was studied in great detail, using surface and deep-tow seismic reflection data, side-scan sonar, bottom sampling, and underwater photography, is the Hamilton Bank area in the Labrador margin, eastern Canada [van der Linden et al., 19761. Below we discuss conclusions and inferences derived from observations of the Labrador shelf that are similar to some of our modeling assumptions and conclusions.

1. The morphology is similar to that of the Antarctic shelf, albeit not as deep, (Figure 6b), and has been permanently submerged since $0.5 \mathrm{Ma}$ [van der Linden et al., 1976], despite the fact that the Laurentide ice sheet no longer exists. Thus, the reverse and overdeepened shelf morphology is not due to loading of an adjacent ice sheet. Moreover, glacial deposits on the Hamilton Bank are unconformably underlain by gently seaward-dipping coastal plain nonglacial strata. If the reverse shelf morphology was due to a dynamic depression from an ice sheet, the underlying nonglacial deposits would have been expected to be tilted inland.

2. The inner shelf trough, which is also underlain by coastal plain strata, shows no evidence for faulting or differential crustal subsidence leading van der Linden $\boldsymbol{e t}$ al. [1976] to conclude that it was due to glacial erosion or preglacial fluvial erosion.

3. The thickest accumulations of glacial drift along the Labrador shelf occur seaward of former outlets of continental ice streams (Figure 6a) leading van der Linden et $a l$. [1976] to conclude that glacial deposits on 


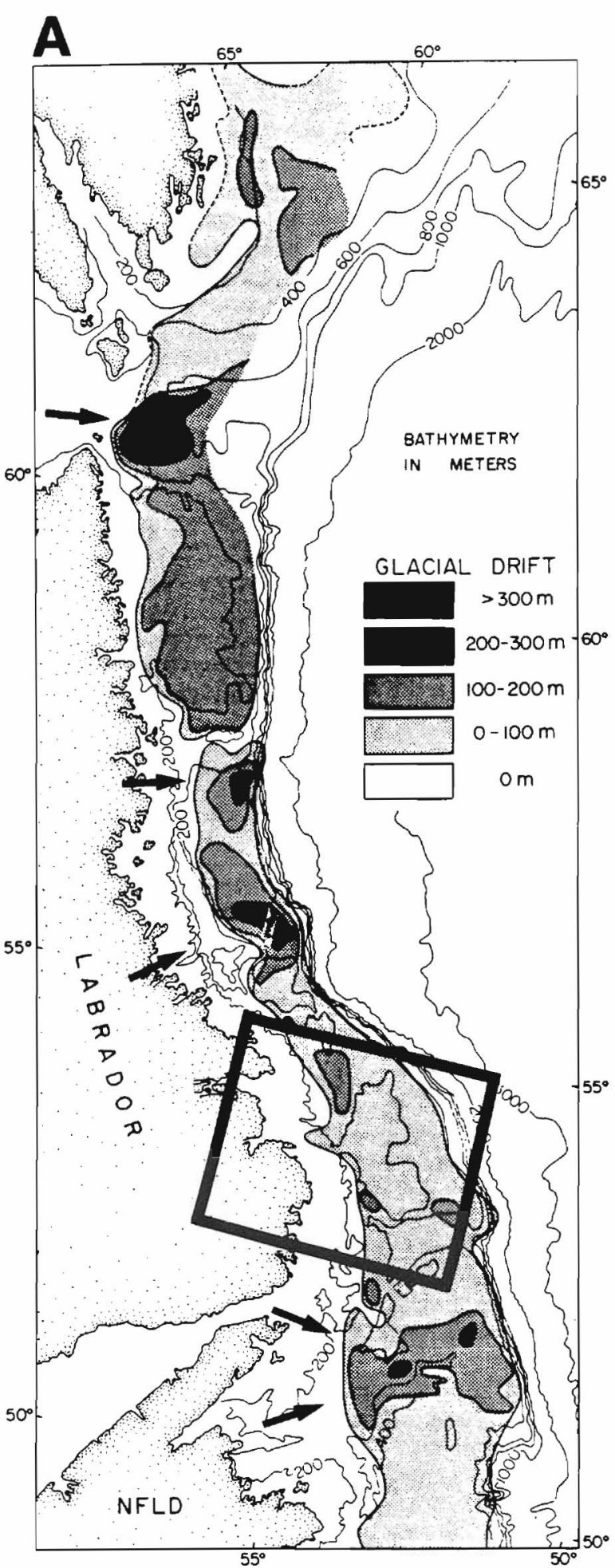

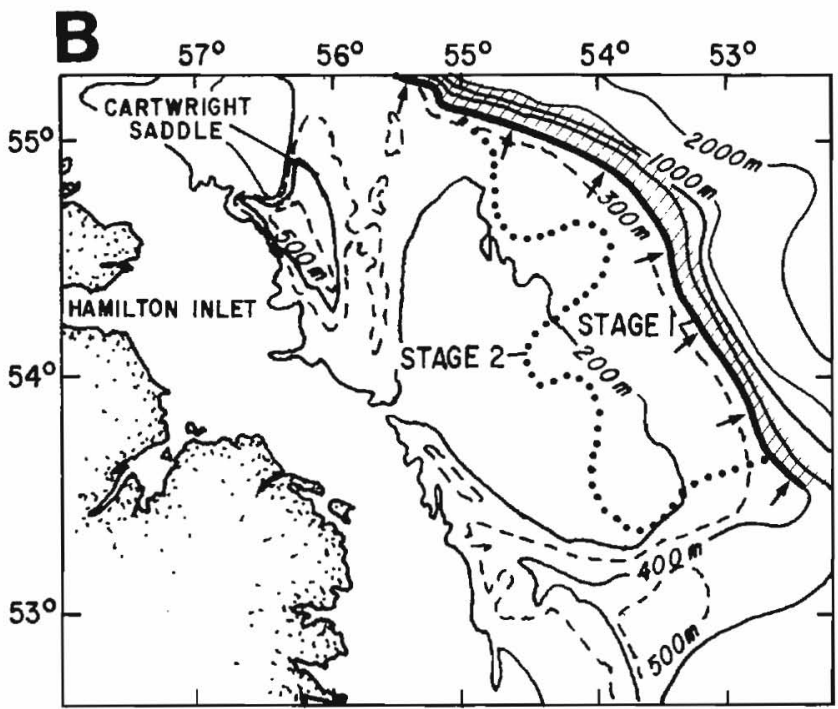

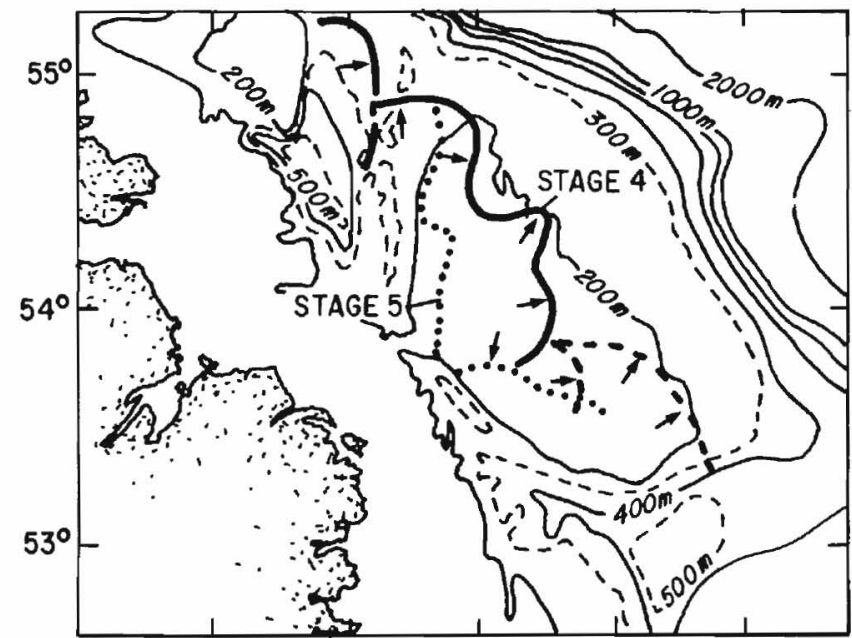

Fig. 6. (A) Isopach map of glacial drift along the Labrador margin, eastern Canada from seismic reflection data (after van der Linden et al., 1976). Arrows - Major glacial outlet.. Frame - Location of map in (B). (B) Successive positions of grounded ice during the last deglaciation [after van der Linden et al., 1976]. Grounded ice advanced after stage 2 to an unknown position (stage 3 ) before retreating to stage 4 . Solid line and arrows (broken lines where uncertain) Grounding line of active ice. Heavy dots - Grounding line of stagnant ice remaining after retreat from active ice position by calving. Hatched area - Inferred floating ice shelves. 
the Labrador shelf have been largely derived from terrestrial sources and not from excavation of the inner-shelf trough.

4. van der Linden et al. [1976] interpreted the grounding line to be in at least 3 different positions between the shelf edge and the coast during the last deglaciation (Figure 6b). This interpretation is in agreement with our conclusion that the grounding line must occupy different positions across the shelf, and not only the coast and the shelf edge. It is also in agreement with the conclusion from Plate 8d that at least across some shelves, erosion and deposition occur during gradual advances and retreats to intermediatepositions.

5. The direction and rate of glacial fluctuations across the Hamilton Bank do not appear to correlate with changes in the $\delta^{18} \mathrm{O}$ anomaly during the Holocene. Although the $\delta^{18} \mathrm{O}$ anomaly dropped since the last glacial maximum, there has been at least one grounding line advance across the Hamilton Bank (Figure 6b). The rate of drop in the $\delta^{18} \mathrm{O}$ ratio accelerated from 18 to 10 $\mathrm{Ka}$ and then decelerated from $10 \mathrm{Ka}$ to the Present [Imbrie et al., 1984]. In contrast, the rate of glacial retreat recorded on Hamilton Bank varied with time. Rapid initial retreat from the shelf edge (stage 1) followed by slower retreat (stage 2). Gradual retreat to an unknown position continued before an advance took place (stage 4). Final ice front retreat was rapid (stage $5)$.

\section{CONCLUSIONS}

We suggest that the depositional sequences and seafloor morphology of the Antarctic shelf are principally the results of time-integrated patterns of glacial erosion and sedimentation relative to the location of the ice grounding line; eustatic changes, tectonic subsidence, and ice loading have only a secondary effect. We envision that the glaciated shelves of Antarctica developed gradually and incrementally over many glacial advances and retreats until they became "mature" (Figure 4c). Drilling results from ODP Leg 119 show, indeed, that the early glacial deposits accumulated in a lacustrineenvironment, whereas later deposits accumulated in deeper marine environment [Humbrey et al., 1991]. The stratigraphy and morphology in the early glacial stages were likely more affected by eustatic and tectonic changes. As the shelf deepened below the range of eustatic changes (100-150 m), however, and acquired its reverse bathymetric profile, eustatic effects on the stratal geometry became less important. The development of the landward-sloping morphology probably caused water-borne proglacial sediments, deposited during nonglaciated and interglacial periods, to be trapped in the inner shelf. Because the inner shelf is, generally, the area of greatest erosion (Figure $\mathbf{3}$ ), these sediments were probably subsequently reworked and transported to the outer shelf and slope regions. Sediments are, therefore, no longer preserved on the shelf in their original form.

Computer simulations of the morphology and stratal geometry of the shelf were used to study the significance and plausibility of different parameters. These simulations yield the following generalizations regarding the processes that form the glaciated Antarctic shelves: (1) Total erosion decreases toward the shelf edge, whereas deposition increases, which creates the observed morphology and stratigraphy. Net erosion (when the total amount of erosion is larger than deposition) is generally confined to the inner shelf and net deposition (when the total amount of deposition is larger than erosion) to the outer shelf. (2) The source of much of tbe glacimarine shelf and slope sediments is probably terrestrial, and not only the eroded preglacial shelf sediments. (3) The ice grounding line probably occupied many different positions across the shelf during many glacial advances and retreats, with some preference toward shelf-edge positions. (4) The shelf morphology and stratal geometry probably developed gradually over many glacial fluctuations to their present mature form. (5) The flexural rigidity of the lithosphere underlying the shelf, and the amount of tectonic subsidence modify the average depth and the bathyrnetric profile of the shelf, but the characteristic inner-shelf trough is usually preserved. (6) Some stratal geometries are probably generated by back-andforth fluctuations of the grounding line, and others by several phases of deposition and erosion during gradual advances and retreats. (7) Stratigraphic simulations suggest that fluctuations in the $\delta^{18} \mathrm{O}$ record for the last 2.5 m.y., which presumably represent fluctuations in global ice volume [Mixet al., in press], does not linearly correlate with the location of the glacier grounding line on the Antarctic shelf. (8) The global sea-level curve by Haq et al. [1988] does not linearly correlate with the location of the glacier grounding line, but the Haq curve may not be detailed enough to simulate glacial fluctuations.

Based on the models, we suggest several guidelines for the stratigraphic interpretation of shelf sediments: (1) Truncations of steeply-dipping prograding sequences with associated unconformities near paleo-shelf edges indicate that grounded ice sheets frequently frequently reach the paleo-shelf edge during glacial maxima. 
Unconformities in the model are also generated by abruptly changing the volume and distribution pattern of deposition. (2) Middle shelf sedimentary layers represent only a partial record of sedimentation $(30-40 \%$ preserved in the referencemodel) during glacial minima because subsequent ice advances erode the layers. The likelihood of preservation increases after several consecutive steps during which ice has been grounded near the coast. (3) Sediments deposited since the initiation of glaciation are probably highly reworked and redistributed over a large area, and consist primarily of glacimarine sediments. They probably rarely preserve evidence of their original depositional environments. (4) An upsection change from progradation to aggradation is a natural consequence of the widening of the shelf with time, however, aggradation can be enhanced by decreasing the input sediment flux with time, or by decreasing the probability that the grounding line will reach the shelf edge.

Acknowledgments Supported by NSF grant OPP-20462 and the U.S. Geological Survey Marine and Coastal Program. We thank J. Anderson, A. Cooper, B. Larsen, H.C. Larsen, and A. Mix for helpful discussions, and S. Shipp for the orignal artwork of Figure 2a. We thank J. Austin, A. Cooper, S. Eittreim, and Y. Kristoffersen for their thorough reviews of the manuscript.

\section{REFERENCES}

Alonso, B., J.B. Anderson, J.T. Diaz and L.R. Bartek, PlioPleistocene seismic stratigraphy of the Ross Sea: evidence for multiple ice-sheet grounding episodes, in Contributions to Antarctic Research, III, Antarctic Research series, v. 57, edited by D. Elliot, 93-103, Amer. Geophys. Union, Washington, D.C., 1992.

Anderson, J.B., The Antarctic continental shelf: results from recent geological and geophysical investigations, in The Geology of Antarctica, edited by R. Tingey, 285334, Oxford University Press, Oxford, 1991.

Anderson, J. B., and Ashley, G. M., Glacial marine sedimentation: Paleoclimatic significance: Geological Society of America Special Paper 261, 225 p., 1991.

Anderson, J.B. and L.R. Bartek, Cenozoic glacial history of the Ross Sea revealed by intermediate resolution seismic reflection data combined with drill site information, in The Antarctic Paleoenvironment: A Perspective on Global Change, Antarctic Research series, v. 56, edited by J. P. Kennett and P. Warnke, 231-263, Amer. Geophys. Union, Washington, D.C., 1992.

Anderson, J.B., P.G. Pope and M.A. Thomas, Evolution and hydrocarbon potential of the northern Antarctic
Peninsula continental shelf, in Antarctica as an Exploration Frontier, edited by W. St. John, 1-12, American Association of Petroleum Geologists, Tulsa, 1990.

Anderson, J.B., S.S. Shipp, L.R. Bartek and D.E. Reid, Evidence for a grounded ice sheet on the Ross Sea continental shelf during the Late Pleistocene and preliminary paleodrainage reconstruction, in Coatributioas to Antarctic Research, III, Antarctic Research series, v. 57, edited by D. Elliot, 39-62, Amer. Geophys. Union, Washington, D.C., 1992.

Andrews, J. H., Late Quaternary marine sediment accumulation in Fjord-shelf-deep-sea transacts, Baffin Island to Baffin Bay, Quaternary Science Reviews, 6, 223-243, 1987.

ANTOSTRAT project, Seismic stratigraphic atlas of the Ross Sea, Antarctica, this volume.

Barron, J, B. Larsen, et al., Proceedings of the Ocean Drilling Program, Initial reports, 119: College Station, Ocean Drilling Program, 942 p., 1989.

Bart, P.J., and J.B. Anderson, Glacial history of the Antarctic Peninsula continental shelf, Terra Anturtica, 1, 263-264, 1994.

Bartek, L.R., P.R. Vail, J.B. Anderson, P.A. Emmet, and S. $\mathrm{Wu}$, Effect of Cenozoic ice-sheet fluctuations in Antarctica on the stratigraphic signature of the Neogene: J. Geophys. Res., 96, 6753-6778, 1991.

Blankenship, D.D., C.R. Bentley, S.T. Rooney and R.B. Alley, Seismic measurements reveal a saturated porous layer beneath an active Antarctic ice stream, Nature, 322, 54-57, 1986.

Boulton, G.S., Sedimentary and sea-level changes during glacial cycles and their control on glacimarine facies architecture, in Glacimarine Environments: Processes and Sediments, edited by J. A. Dowdeswell and J. D. Scourse, 15-52, Geological Society Spec. Publ., Boulder, 1990.

Cooper, A.K., F.J. Davey and K. Hinz, Crustal extension and origin of sedimentary basins beneath the Ross Sea and the Ross Ice Shelf, Antarctica, in Geological Evolution of Antarctica, edited by M. R. A. Thomson, J. A. Crame and J. W. Thomson, 285-291, Cambridge Univ. Press, Cambridge, 1991a.

Cooper, A.K., P.J. Barrett, K. Hinz, V. Traube, G. Leitchenkov and H.M.J. Stagg, Cenozoic prograding sequences of the Antarctic continental margin: A record of glacio-eustatic and tectonic events, Mar. Geol., 102, 175-213, $1991 b$.

Cooper, A.K., S. Eittreim, U. ten Brink and I. Zayatz, Cenozoic glacial sequences of the Antarctic continental margin as recorders of Antarctic ice-sheet fluctuations, in The Antarctic Paleoenvironment: A Perspective on Global Change, Antarctic Research series, v. 60, Edited by J. Kennett, American Geophysical Union, pp. 75-89, 1993.

Domack, E. W., A.T.J. Jull and S. Nakao, Advance of East Antarctica outlet glaciers during the Hypsothermal: Implications for the volume state of the Antarctic ice 
sheet under global warming: Geology, 19, 1059-1062, 1991.

Drewry, D., Glacial Geologic Processes, London, Edward Arnold, 276 p., 1976.

Feller, W., An Introduction to Probability Theory and its Applicutions, 509 pp., John Wiley \& Sons, New York, 1968.

Eittreim, S.L., A.K. Cooper, and J. Wannesson, Seismic stratigraphic evidence of ice-sheet advances on the Wilkes Land margin of Antarctica, Sed. Geol., 96, 131156, 1995.

Hambrey, M. J., W.U. Ehrmann, and B. Larsen, B., Cenozoic glacial record of the Prydz Bay continental shelf, in Proceedings of the Oceun Drilling Program, Scientific Results, edited by J. Barron, B. Larsen, B., et al.: College Station, Texas, Ocean Drilling Program, 119, 77-132, 1991.

Haq, B.U., J. Hardenbol, and P.R. Vail, Mesozoic and Cenozoic chronostratigraphy and cycles of sea-level change, Soc. Econom. Paleontol. Mineral. Spec. Pub., 42, 71-108, 1988.

Harden, S.L., D.J. DeMaster and C.A. Nittrouer, Developing sediment geochronologies for high-latitude continental shelf deposits: a radiochemical approach, Mar. Geol., 103, 69-97, 1992.

Imbrie, J., J.D. Hays, D.G. Martinson, A. McIntyre, A.C. Mix, J.J. Morley, N.G. Pisias, W.L. Prell and N.J. Shackleton, The orbital theory of Pleistocene climatesupport from a revised chronology of the marine $\delta^{18} \mathrm{O}$ record, in Milankovitch and Climate, Part I. edited by A. L. Berger et al., 269-305, D. Reidel Publishing Co., Boston, 1984.

Johnson, G.L., J.R. Vanney and D. Hayes, The Antarctic continental shelf, in Antarctic Geoscience, edited by $\boldsymbol{C}$. Craddock, 995-1002, University of Wisconsin Press, Madison, 1982.

Larsen, H.C., A.D. Saunders, P.D. Clift, J. Beget, W. Wei , S. Spezzaferri and ODP Leg 152 Scientific Party, Seven million years of glaciation in Greenland, Science, 264, 952-955, 1994.

Larter, R.D. and P.F. Barker, Neogene interaction of tectonic and glacial processes at the Pacific margin of the Antarctic Peninsula, Spec. Publ. Int. Ass. Sediment., 12, 165-186, 1991.

Larter, R.D. and A.P. Cunningham, The depositional pattern and distribution og glacial-interglacial sequences on the Antarctic Peninsula Pacific margin, Mar. Geol., 109, 203-219, 1993.

Larter, R.D., and V.E. Vanneste, L.E., Relict subglacial deltas on the Antarctic Peninsula outer shelf, Geology, 23, 33-36, 1995.

Lawver, L.A., J.-Y. Royer, D.T. Sandwell and C.R. Scotese, Evolution of the Antarctic continental margins, in
Geological Evolution of Antarctica, edited by M. R. A. Thomson, J. A. Crame and J. W. Thomson, 533-539, Cambridge Univ. Press, Cambridge, 1991.

Mix, A. and W.F. Ruddirnan, Structure and timing of the last deglaciation: Oxygen-isotope evidence, Quater. Sci. Res., 4, 59-108, 1985.

Mix, A.C., N.G. Pisias, W. Rugh, J. Wilson, A. Morey and T.K. Hagelberg, Benthic foramenifer stable isotope record from Site 849, 0-5 MA: Local and global climate changes, in Proceedings of the Oceun Drilling Program, Scientific Results, edited by N. G. Pisias et al., Ocean Drilling Program, College Station, TX, in press.

Paterson, W.S.B., The Physics of Glaciers, 480 pp., Pergamon, Oxford, 1994.

Pope, P.G. and J.B. Anderson, Late Quaternary glacial history of the northern Antarctic Peninsula's western continental shelf: Evidence from the marine record, in Contributions to Antarctic Research, 111, Antarctic Research series, v. 57, edited by D. Elliot, 63-91, Amer. Geophys. Union, Washington, D.C., 1992.

Powell, R.D., Glacimarine processes at grounding line fans and their growth to ice-contact deltas, in Glacirnarine Environments: Processes und Sediments, edited by J. A. Dowdeswell and J. D. Scourse, 53-73, Geological Society Spec. Publ., Boulder, 1990.

Syvitski, J.P.M., On the deposition of sediment within glacier-influenced fjords: oceanographic controls, Mar. Geol., 85, 301-329, 1989.

ten Brink. U.S. and A.K. Cooper, Modeling the bathymetry of the Antarctic continental shelf, in Recent Progress in Antarctic Earth Sciences, edited by $\boldsymbol{Y}$. Yoshida, K. Kaminuma and K. Shiraishi, 763-771, TERRAPUB, Tokyo, 1992.

ten Brink, U.S. and C. Schneider, Glacial morphology and depositional sequences of the Antarctic continental shelf, Geology, in press.

van der Linden, W.J., R.H. Fillon and D. Monahan, Hamilton Bank. Labrador margin: Origin and evolution of a glaciated shelf, Geol. Survey Canada Pap.,75-40, 31, 1976.

A.H. Johnson, U.S. Geological Survey, Quissett Campus, 384 Woods Hole Road, Woods Hole, MA 02543

C. Schneider, Department of Geosciences Pennsylvania State University, University Park, PA 16802

U.S. ten Brink, U.S. Geological Survey, Quissett Campus, 384 Woods Hole Road, Woods Hole, MA 02543

(E-mail: tenbrink@nobska.er.usgs.gov)

(Received February 14, 1995; accepted May 11, 1995.) 